Chicago-Kent College of Law

Scholarly Commons @ IIT Chicago-Kent College of Law

February 2006

\title{
Law and the Fabric of the Everyday: Settlement Houses, Sociological Jurisprudence, and the Gendering of Urban Legal Culture
}

Felice J. Batlan

IIT Chicago-Kent College of Law, fbatlan@kentlaw.iit.edu

Follow this and additional works at: https://scholarship.kentlaw.iit.edu/fac_schol

Part of the Legal History Commons

\section{Recommended Citation}

Felice J. Batlan, Law and the Fabric of the Everyday: Settlement Houses, Sociological Jurisprudence, and the Gendering of Urban Legal Culture, 15 S. Cal. Interdisc. L.J. 235 (2006).

Available at: https://scholarship.kentlaw.iit.edu/fac_schol/70

This Article is brought to you for free and open access by the Faculty Scholarship at Scholarly Commons @ IIT Chicago-Kent College of Law. It has been accepted for inclusion in All Faculty Scholarship by an authorized administrator of Scholarly Commons @ IIT Chicago-Kent College of Law. For more information, please contact jwenger@kentlaw.iit.edu, ebarney@kentlaw.iit.edu. 


\title{
LAW AND THE FABRIC OF THE EVERYDAY: THE SETTLEMENT HOUSES, SOCIOLOGICAL JURISPRUDENCE, AND THE GENDERING OF URBAN LEGAL CULTURE
}

\author{
FELICE BATLAN ${ }^{*}$
}

\section{INTRODUCTION}

This Article argues that at the turn of the twentieth century, settlement houses were particularly important and vibrant legal sites, in which women settlement workers played groundbreaking and multiple legal roles. ${ }^{1}$ Settlement houses created a geographical and intellectual space where diverse parties participated in analyzing, examining, discussing, popularizing, producing, and reforming law. More broadly, settlement houses were part of a rich and prolific urban legal environment that produced and prompted legal innovation and experimentation. Surprisingly, however, legal scholars have almost entirely neglected the groundbreaking legal work that settlement houses performed. ${ }^{2}$ Such neglect results in an impoverished understanding of fin-de-siecle legal reform and fails to uncover the central role that middle-class and elite women played as providers of legal services and transmitters of legal knowledge. This Article seeks to begin to rectify this situation and to prompt a dialogue about how we conceptualize the ways in which settlement houses contributed to and propagated legal reform and the central role that women and gender played in structuring such issues.

\footnotetext{
* Associate Professor of Law, Tulane Law School; Adjunct Professor of History, Tulane University. B.A., Smith College; J.D., Harvard Law School; Ph.D., New York University. For their insightful and helpful comments the author thanks Thomas Bender, Linda Gordon, William E. Nelson, Richard Bernstein, Jonathan Nash, Marjorie Kornhauser, Pamela Metzger, the Tulane Faculty Workshop and the NYU Legal History Symposium. Special gratitude to Kristin Lyman research assistant par excellence.

1 Settlement houses might be described as early versions of community centers located in poor immigrant urban areas. See infra Part I.A.

${ }^{2}$ A small number of legal works mention settlement houses but none provide a sustained discussion or analysis. See, e.g., Anthony Bertelli, Should Social Workers Engage in the Unauthorized Practice of Law?, 8 B.U. PUB. INT. L.J. 15, 26 (1998) (pointing to settlement houses in arguing that social workers should be allowed to provide legal services to the poor); Deborah Cantrell, $A$ Short History of Poverty Lawyers in the United States, 5 LOY. J. PUB. INT. L. 11, 12-13 (2004) (exploring how settlement houses used law to seek structural reform in contrast to the more conservative Legal Aid Society of New York). On the history of the Legal Aid Society, see generally JOHN MACARTHUR MAGUIRE, THE LANCE OF JUSTICE: A SEMI-CENTENNIAL HISTORY OF THE LEGAL AID SOCIETY 1876-1926 (Harvard University Press 1928); HARRISON TWEED, THE LEGAL AID SOCIETY: NEW YORK CITY 1876-1951 (1954).
} 
This Article makes five principal points. First, settlement houses created a new location where a wide range of legal services and legal knowledge could be delivered and transmitted to the poor. Second, settlement workers hoped to Americanize immigrants through law by inculcating the importance of the rule of law pursuant to which immigrants became aware of their rights as well as of their legal obligations and duties. Third, under the rubric of philanthropy and the nascent field of social work, settlement house work allowed middle class and elite women to essentially engage in the practice of law. Fourth, the settlements birthed a new conception of law- one that was deeply grounded in the daily life of the home and neighborhood and often the domestic work that women performed. In doing so, settlement houses created a novel jurisprudence and way of practicing law that would later resonate with sociological jurisprudence. ${ }^{3}$ Finally this constellation of issues regarding gender and Americanization created a situation in which immigrant women often came under the intense scrutiny of settlement workers. Thus we must understand the legacy of the settlement houses as ambiguous and as presenting multiple layers of complexity. On the one hand, settlement workers envisioned a new type of legal practice in which numerous services and legal knowledge would be delivered to the poor, but on the other hand, through the law, settlement workers often imposed their own sense of morals and what constituted appropriate home life and public order upon immigrants. ${ }^{4}$

This Article is essentially a micro history, as it intensely focuses on the settlement houses of New York City. It does so for a number of reasons. First, settlement houses in the United States originated in New York City and the largest concentration of settlement houses were located there.

\footnotetext{
${ }^{3}$ Sociological jurisprudence was a school of legal thought and practice that emerged at the turn of the twentieth century. See infra Part II.D.

${ }^{4}$ The history and legacy of settlement houses has implications for how poverty law and community lawyering are currently practiced. This is important because the past decade has seen a renewed interest in public interest community lawyering. At its most basic, community lawyering involves attomeys becoming part of the communities (usually poor and urban) where they practice. It also involves breaching the disciplinary borders that separate lawyering from social work and an individual's legal problems from larger social and economic factors. Such lawyering often embraces a "holistic" approach to the client and her problems. It understands that only one facet of the client's needs may require traditional legal responses and that the client may have multiple unmet needs that contribute to the legal problem. In particular, community and holistic lawyering require a multi-disciplined approach in which a wide variety of professionals bring their skills to aiding the client. By examining the role of settlement houses at the turn of the century, this Article enables us to understand an earlier version of community lawyering as well as the larger ideological structures that produced settlement houses. Gerald Lopez has written some of the most persuasive work on community lawyering. See generally GERALD LOPEZ, ReBellious LAWYERING: ONE CHICANO'S VISION OF PROGRESSIVE LAW PRACTICE (1992); Gerald Lopez, Shaping Community Problem Solving Around Community Knowledge, 79 N.Y.U. L. REv. 59 (2004). Michael Diamond writes that community lawyering involves a practice that is "located in poor, disempowered, and subordinated communities and is dedicated to serving the communities' goals," including providing basic legal services. Michael Diamond, Community Lawyering: Revisiting the Old Neighborhood, 32 ColUM. HUM. RTS. L. REV. 67, 75 (2000). On specific community lawyering projects, see Douglas Ammar \& Tosha Downey, Transformative Criminal Defense Practice: Truth, Love, And Individual Right-The Innovative Approach of the Georgia Justice Project, 31 FORDHAM URB. L.J. 49 (2003) (discussing the Georgia Justice Project).

${ }^{5}$ Between 1886 and 1903 , over twenty-nine settlements had been established in New York City. The best known of these houses were University Settlement (1886), College Settlement (1889), Henry Street Settlement (1893), Union Settlement (1895), Hudson Guild (1895), Hartley House (1897), Madison
} 
Second, New York, which was the country's largest city, experienced the profound problems which arose from massive immigration and industrialization. ${ }^{6}$ Third, New York as a cultural and intellectual center also attracted some of the best young minds of the generation and proved to be a hospitable location for single women. ${ }^{7}$ Indeed, in reform efforts, New York was rivaled only by Chicago. ${ }^{8}$ Since this is the first significant effort to conceptualize settlement houses as important legal sites, a micro study is necessary and will hopefully prompt further exploration of settlement houses in other cities, which may allow for the accounting of regional and local differences.

The Article proceeds as follows: Part II sets forth the origins of settlement houses and how they understood and sought to implement their goals and missions. It also begins to analyze how the settlements used law and how law fit into their larger methodology, social agenda, and ideology. It concludes by starting to draw the connections between the settlement houses' use and understanding of law with academics' early formations and articulations of what a new sociological jurisprudence might entail. Departing from most legal scholarship on sociological jurisprudence, I conclude that this school of thought percolated down from the settlement houses into elite legal thought and that middle-class women played a significant role in its development.

Part III examines how settlement houses in New York City provided direct legal aid to clients and the role that women attorneys played in that process. This Part also explores how the settlements' use and conception of the law went far beyond the provision of formal legal aid, encompassing informal methods of providing legal help that served to spread and popularize legal knowledge. In particular, it shows that settlement workers understood law as one avenue through which immigrants could be "Americanized."

Part IV analyzes New York City's settlement houses' close connections with city government and how settlement workers, often women, were able to call upon, and at times directly exercise, state power. In the process, settlement workers also exerted significant social control over their neighborhoods and the people they served, especially immigrant women. At other moments, settlement workers functioned as important intermediaries, bringing the complaints and needs of neighbors to the attention of the municipal government and demanding that the government enforce laws.

Part V examines University Settlement House's massive study of installment contracts and the legal process surrounding them. I use this

Settlement (1898), and Greenwich House (1902). See HARRY P. KRAUS, THE SETTLEMENT House MOVEMENT IN NEW YORK CITY, 1886-1914 (Steve Bedney ed., 1980).

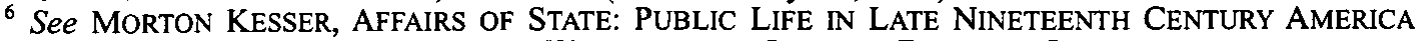
(1977); ELIZABETH EWEN, IMMIGRANT WOMEN IN THE LAND OF DOLLARS: LIFE AND CULTURE ON THE LOWER EAST SIDE (1985).

${ }^{7}$ See THOMAS BENDER, NEW YORK INTELLECT: A HISTORY OF INTELLECTUAL LIFE IN NEW YORK CITY FROM 1750 TO THE BEGINNINGS OF OUR OWN TIME (1987).

${ }^{8}$ See id. 
study to demonstrate how the settlements broadly defined legal problems and understood that body of law, as well as economic and social conditions, which led to the widespread use and abuse of that law. This Part then discuses some of the reforms that the settlement sought to enact. Simultaneously, it explores how perceptions of gender and immigrants shaped and contoured their study, findings, and recommendations.

The final Part explicates the role that settlements played within the courts of New York City. Settlements saw municipal courts as crucial institutions within a community and as places in which settlement workers' participation could serve a variety of needs. Specifically, Part VI examines the roles that settlement workers played in eviction proceedings and as probation officers. It argues that such workers, men and women, were able to exercise tremendous influence over the courts. Further, it shows that they were guided by the objective of seeking justice in the individual case and that they had an understanding that formal legal rules often subverted justice. In doing so, however, their own middle-class conceptions of morality and appropriate behavior shaped their determinations.

\section{THE RISE OF THE SETTLEMENT HOUSE MOVEMENT}

This Part discusses what settlement houses were, how they functioned, the multiple factors that created the conditions for their development and proliferation, and the ideology that drove them. It then briefly elucidates how various historians have interpreted the importance of settlement houses and argues that scholars have overlooked the ways in which settlement houses were deeply involved in law and legal reform. To understand settlement workers' interactions with law and the manner in which they conceptualized law, I explain how settlements conceived of knowledge and how such formulations allowed workers, especially women, to position themselves as experts. I then begin the process of showing how settlement houses began to lay the foundation for an on-the-ground sociological jurisprudence that later academics would claim as their own.

\section{A. The SeTtlement House Movement}

A variety of reformers established the first settlement houses in the United States in the late $1880 \mathrm{~s}^{9}{ }^{9}$ Two of the earliest and most famous settlement founders were Jane Addams of Hull House in Chicago and Lillian Wald of Henry Street Settlement in New York City. ${ }^{10}$ In the next two decades, settlements proliferated across the cities of the United States. ${ }^{11}$ For example, in 1891 there were six settlements, in 1897 there were seventy-

\footnotetext{
${ }^{9}$ The idea of settlement houses was planted as elite and middle-class Americans learned of and visited Toynbee Hall in the East End of London. Toynbee Hall was established in 1884 by recent graduates of Oxford University who were committed to providing services to the poor. See MINA CARSON, SETTLEMENT FOLK: SOCIAL THOUGHT AND THE AMERICAN SETTLEMENT MOVEMENT 1 (1990).

${ }^{10}$ See JeAN BethKe Elshtain, THE JANE AdDAMS READER (2002); AllEN DAVIS, SPEARHEADS FOR REFoRM: THE SOCIAL SETTLEMENTS AND THE PROGRESSIVE MOVEMENT, 1890-1914, 12 (1967).

$"$ See DAVIS, supra note 10 , at 12.
} 
four, and in 1910 there were more than four hundred. ${ }^{12}$ On its most rudimentary level, settlement houses were residences established by elite and middle class women and men in poor urban immigrant neighborhoods. ${ }^{13}$ In each case, the settlement was created to resemble a middle-class home that was open to the public. ${ }^{14}$ Some settlement workers actually lived in the settlement house while others worked there. ${ }^{15}$ Settlement houses were born in a spirit of improvisation and flexibility, motivated by the idea that they would provide services, as needs arose, to the neighborhoods in which they were located. ${ }^{16}$ They further embraced the understanding that poverty was the result of structural economic and social issues, not individual fault. ${ }^{17}$

Early settlement founders and workers believed that they would settle in a house located in a poor urban area, become acquainted with their neighbors, and then begin to provide whatever non-monetary aid a community required. ${ }^{18}$ Central to the project was the idea that settlement workers would become part of the community. ${ }^{19}$ Over the years, settlement houses opened cafeterias and provided English classes, cooking classes, and a host of other courses for children and adults. ${ }^{20}$ They also built playgrounds, ran summer camps, sponsored lectures, art exhibits, and plays, taught vocational skills, and provided a physical meeting space for a wide range of organizations including labor unions. ${ }^{21}$ Settlement house founder Mary Kingsbury Simkhovitch eloquently described settlements as follows:

The aim of the settlement or neighborhood house is to bring about a new kind of community life. It is the home of friendly neighbors, and a center for information, organization and service ... The house should organize the interests of the neighborhood, social, cultural, artistic and intellectual ... The house should render services to families, individuals, and to the neighborhood. ${ }^{22}$

Part of what accounted for the success of the settlement movement was its flexibility in responding to what settlement workers perceived as a community's continually changing needs. ${ }^{23}$

${ }^{12}$ See id.

${ }^{13}$ See id. at 8-14.

${ }^{14}$ See $i d$. at 26 ; JeAn BethKe Elshtain, JANE AdDAMS AND THE DREAM OF AMERICAN DEMOCRACY: A LIFE 90-91 (2002)

is Settlements referred to workers who actually lived in a settlement house as "residents" or "workers." Volunteers and paid employees who worked for the settlement were referred to as "workers" and people who used the resources of the settlements as "neighbors." See JANE ADDAMS, TWENTY YEARS AT HULLHOUSE 60-65 (1911). For historical accuracy, I use "neighbor" rather than client.

${ }_{17}^{16}$ See ElSHTAIN, supra note 14, at 92-94; ADDAMS, supra note 15 , at 75.

17 See DAVIS, supra note 10, at 18.

${ }_{1}^{18}$ See ADDAMS, supra note 15 , at 54-58; LILlian D. WALD, THE HOUSE ON HENRY STREET 8-9 (1935).

${ }^{19}$ See, ADDAMS, supra note 15 , at 76.

${ }^{20}$ See ELSHTAIN, supra note 14 , at 92.

${ }^{21}$ See id; see also ALBERT KENNEDY \& KATHRYN FARRA, SOCIAL SETTLEMENTS IN NEW YORK CITY (1935).

22 Mary Kingsbury Simkhovitch, The Settlement Primer: A Handbook for Neighborhood WORKERS 9 (2d ed.1936).

${ }^{23}$ See ADDAMS, supra note 15, at 77-91; LILlIAN D. WALD, WINDOWS ON HENRY STREET 6-7 (1934). 
The first generation of settlement workers shared many traits. As a group, they tended to be young. ${ }^{24}$ Jane Addams was twenty-nine when she established Hull House, and the women who founded College Settlement were all under thirty. ${ }^{25}$ The workers also had obtained a remarkably high level of education, as more than ninety percent had a college education and more than fifty percent had done graduate work. ${ }^{26}$ These numbers are particularly astounding for women settlement workers when one recognizes how unusual it was for women to attend university. ${ }^{27}$ Further, settlement workers tended to be unmarried, which at times, caused critics to charge that settlements were havens for "old maids." 28 Although this perception changed through the years and varied by locality, workers tended to come from "old-stock American families" and were primarily raised in urban areas in the Northeast and Midwest. ${ }^{29}$ A notable exception to this was Lillian Wald, who came from a German-Jewish family. ${ }^{30}$ However, like other workers, Wald was raised in a well-to-do family. ${ }^{31}$ Settlement workers' fathers were often ministers, teachers, doctors, or attorneys; and workers often came from families involved in charitable and philanthropic organizations. ${ }^{32}$ A 1906 survey of 170 settlement houses found a total of 837 settlement workers who resided in settlement houses and 3,907 nonresident workers, of which 2,930 were women and 977 men $^{33}$ Fifty-five thousand people used the facilities of the settlements surveyed. ${ }^{34}$

The rise of settlement houses was a response to a variety of social conditions that coalesced at the turn of the century, including the massive influx of immigrants into the country's cities ${ }^{35}$ The wave of immigration that occurred in the late nineteenth century brought Southern Europeans and Eastern European Jews. ${ }^{36}$ Most of these immigrants were poor and considered by conventional wisdom as unable to assimilate into American society. ${ }^{37}$ Settlements were also a response to what was perceived as growing urban poverty and the lack of an effective state to provide social services. Further, as labor activity increased and with it often violent strife between labor and capital, settlements sought to ameliorate class conflict through their presence and the services they provided by creating common

\footnotetext{
${ }^{24}$ See DAVIS, supra note 10 , at 33.

${ }^{25}$ See id.

${ }^{26}$ See id. at 33-34.

${ }^{27}$ See infra note 37.

${ }^{28}$ See DAVIS, supra note 10 , at 34.

${ }^{29}$ Id.

${ }^{30}$ See id. at 12.

31 See Doris Groshen DANIElS, AlWAys A SiSTER: THE FEMINISM OF LILlian D. WALD (1989).

32 See DAVIS, supra note 10, at 35-36.

${ }^{33}$ See The New EncYClopedia of Social ReForm 1107 (William Dwight Porter Bliss \& Rudolph M. Binder eds., 1908).

${ }^{34}$ See id.

35 See Jane Addams, The Objective Value of Social Settlement, in THE JANE ADDAMS READER 29 (Jean Bethke Elshtain ed., 2002); RIVKA SHPAK LISSAK, PLURALISM AND PROGRESSIVISM: HULl HOUSE AND THE NEW IMMIGRANTS, 1890-1919 (1989).

${ }^{36}$ See EWEN, supra note 6, at 21 .

${ }^{37}$ In 1870 , the U.S. population was made up of $4,941,049$ immigrants from Europe. By 1900, the number of European immigrants had increased to $8,881,548$. See Campbell Gibson \& Emily Lennon, Region of Birth of the Foreign-Born Population: 1850 to 1930 and 1960 to 1990 (March 9, 1999), http://www.census.gov/population/www/documentation/twps0029/ tab02.html.
} 
projects and allowing the poor and rich to meet while working for similar goals. ${ }^{38}$ As Mary Kingsbury Simkhovitch succinctly, if optimistically, recalled about the founding of Greenwich Settlement,

[O]ur whole thought of the settlement was that it must be a group of friends, who, together with the neighbors, would through a common experience build up common enthusiasm for common projects ... If social improvements are to be undertaken by one class on behalf of another, no permanent changes are likely to be effected. The participation by all concerned is necessary for sound improvement. ${ }^{39}$

Both the needs of the community and the needs of those who would work there spurred the rise of the settlement houses. This was in part due to the fact that following the Civil War, the opportunities for women to obtain a higher education dramatically increased. ${ }^{40}$ As these women graduated college, most professions were closed to them. Searching for a way in which to justify their education, while engaging in the "appropriate" female behavior of caring for others, many found settlement houses and the work that it offered appealing. Settlements further provided an acceptable alternative for women who chose not to marry immediately (or marry at all) and in a certain sense, settlements created an alternative family structure for such women at a time when it was still highly unusual for single women to live alone. Indeed settlements created cooperative housekeeping arrangements, freeing women from many domestic chores, while also creating a stimulating intellectual space. Furthermore, as many of these settlements were open only to women residents, they reproduced the conditions of the women's colleges in which some settlement workers were educated, including the opportunity for female leadership. ${ }^{41}$ Women like Jane Addams, Vida Scudder, and Lillian Wald began to forge new opportunities to create adventurous, useful, and fulfilling lives through their

\footnotetext{
${ }^{38}$ Hudson Guild wrote that its activities allowed capital and labor to "unite and work together to accomplish good results which none of them could achieve alone." HUDSON GUILD, 1895-1927, 4-5 (1927). On labor union activity and strikes at the turn of the century, see ADDAMS, supra note 15, at 18 (discussing the Pullman strike); ARNOLD M. PAUL, CONSERVATIVE CRISIS AND THE RULE OF LAW: ATTITUDES OF BAR AND BENCH, 1887-1895, at 1-2, 19-20, 131-42 (1960). One historian writes of settlement houses, "They saw their role as mediators between competing social and economic interests, interpreters shuttling between the alien cultures of the recent immigrants and the entrenched and defensive "natives." CARSON, supra note 9, at 53.

${ }^{39}$ MARY KINGSBURY SimKHOVITCH, NEIGHBORHOOD: MY STORY OF GREENWICH HOUSE 93 (1938). Hudson Guild echoed these sentiments stating that it, "[B]rought to sometimes antagonistic groups new ways of living and working together; a new cooperation; a new democracy." HUDSON GUILD, 18951927, 3 (1927).

${ }^{40}$ Smith and Wellesley both opened in 1875. Bryn Mawr followed in 1885. In addition, numerous coeducational public universities opened. See JoEllen Lind, Symbols, Leaders, Practitioners: The First Women Professionals, 28 VAL. U. L. REV. 1327, 1351-52 (1994). On women's higher education, see NANCY F. COTT, THE GROUNDING OF MODERN FEMINISM 22, 40, 148 (1987); HELEN LEFKOWITZ HOROWITZ, ALMA MATER: DESIGN AND EXPERIENCE IN THE WOMEN'S COLlEGES FROM THEIR NiNETEENTH-CENTURY BEGINNINGS TO THE 1930s (1984); HELEN LEFKOWITZ HOROWITZ, CAMPUS LIFE: UNDERGRADUATE CULTURES FROM THE END OF THE EIGHTEENTH CENTURY TO THE PRESENT (1987); HELEN LEFKOWITZ HOROWITZ, THE POWER AND PASSION OF M. CAREY THOMAS (1994).

${ }^{41}$ See Kathry Kish SKLaR, Florence Kelley \& THE Nation's WORK: THE Rise OF WOMEN'S POLITICAL CULTURE, 200-05 (1995).
} 
work in settlement houses. ${ }^{42}$ These women founders recognized that settlement work provided as much (if not more) to the settlement worker as the worker provided to the community. ${ }^{43}$

Even in those settlement houses organized and managed by men and that only accepted men as full-time residents, women performed important functions. ${ }^{44}$ For instance, New York City's University Settlement House was run and controlled by men, yet one head resident reported,

[T] he people connected with the Settlement who are doing the most valued work, and whose lives are in a very real sense a fine influence among the people of the neighborhood, are the women workers, who spend a large part of each day in the actual work of the Settlement. ${ }^{45}$

Other settlements, such as New York City's College Settlement and Henry Street Settlement, were established and controlled by women and accommodated only women residents. ${ }^{46}$ Greenwich Settlement, although allowing both male and female residents, was founded and managed by Mary Kingsbury Simkhovitch. ${ }^{47}$ Indeed, through the settlements, middleclass and elite women forged significant careers and relationships with city and state officials while amassing considerable power.

Furthermore, as contemporaries remarked, settlement houses tended to attract as clients immigrant women and children. ${ }^{48}$ They had more difficulty drawing immigrant men into their fold and convincing them to use the facilities and services of the settlement houses. ${ }^{49}$ Historian Allen Davis writes, "Perhaps the most serious limitation of all was that the settlements failed to attract the men in the neighborhood." considers a disadvantage was in fact an advantage to women settlement workers, as they were considered naturally suited to minister to other women.

Historians, as well as the leaders of the various settlement houses, have emphasized such houses' multiple accomplishments and missions. They were sites of urban democracy, island communities in otherwise vast and anonymous cities, mediums through which the Americanization of immigrants occurred, primary centers for imparting education and culture to immigrants, and one of the principal locations in which the profession of

\footnotetext{
${ }^{42}$ All three of these women wrote autobiographies discussing how they became involved in settlement work and what settlement work meant to them. See ADDAMS, supra note 38; VIDA DUTTON SCUDDER, ON JOURNEY (1937); WALD, supra note 23.

${ }^{43}$ See Jane Addams, The Subjective Necessity for Social Settlements, in THE JANE ADDAMS READER 14 (Jean Bethke Elshtain ed., 2002).

44 See CARSON, supra note 9, at 197.

${ }^{45}$ House for Women Workers, Records of University Settlement Society of New York City, in THE JACOB S. EISENGER COLLECTION, WISCONSIN HISTORICAL SOCIETY, 2, Box 3 (Apr. 1902). For example, in 1896, University Settlement listed sixty-four workers, of whom forty-eight were women. UNIV. SETTLEMENT SOC'Y, REPORT FOR THE YEAR 1896 (1896).

${ }^{46}$ See KRAUS, supra note 5.

${ }_{48}^{47}$ See SIMKHOVITCH, supra note 22.

${ }_{48}^{48}$ See DAVIS, supra note 10 , at 88.

${ }^{49}$ See id.

${ }^{50}$ Id.
} 
social work developed. ${ }^{51}$ They have also been criticized for imposing middle class "American" values on immigrants and functioning as agents of social control. ${ }^{52}$ Of course, settlement workers brought to the settlements their own bourgeois understandings of what constituted the public good, and especially how family, gender, and work relations should be structured. Thus, as will be seen, even while they reached out to neighbors and attempted to bring them within the fold of the settlement houses, they also often exerted various types of control, including state control over their neighbors, while enacting into law what they understood to be in the best interests of the neighborhood, the city, and the nation. ${ }^{53}$

\section{B. LAW, AMERICANIZATION, AND THE SETTLEMENT HOUSES}

Settlement house workers viewed law as providing one means through which immigrants could be transformed into American citizens. As understood by the settlement houses, part of the process of transformation required the immigrant to develop a respect for and knowledge of American law and the legal process. Settlement houses' legal work took a number of forms, including inculcating discipline and obedience to law. It also, however, encompassed making immigrants aware of their legal rights and obligations, showing how the American legal system functioned, and providing immigrants with the ability to obtain legal assistance. Lillian Wald emphasized that workers should help immigrants "understand the requirements of Anglo-Saxon law and order and to bring to them a conception of American ideals that will go far towards creating among immigrants a realization of what is good in American life." 54 To become

\footnotetext{
${ }^{51}$ The literature on settlement houses is vast, although none of it discusses the important legal role that settlements played. For some of the most important scholarship, see generally CARSON, supra note 9; DANIELS, supra note 31; DAVIS, supra note 10; EDWARD DEVINE, WHEN SOCIAL WORK WAS YOUNG (1939); ARTHUR HOLDEN, THE SETTLEMENT IDEA: A VISION OF SOCIAL JUSTICE (1922); KRAUS, supra note 5; ElizABETH LASCH-QUINN, BLACK NEIGHBORS: RACE AND THE LIMITS OF REFORM IN THE AMERICAN SETTLEMENT HOUSE MOVEMENT, 1896-1945 (1993); SCUDDER, supra note 42; SIMKHOVITCH, supra note 39; WALD, supra note 18. The literature on settlement houses in Chicago, especially Jane Addams' Hull House, is more extensive than scholarship on settlements in New York City. See generally ADDAMS, supra note 15; ALlEN DAVIS, AMERICAN HEROINE: THE LIFE AND LEGEND OF JANE ADDAMS (1973); ELSHTAIN, supra note 14; LISSAK, supra note 35; ROBYN MUNCY, Creating a Female Dominion of AMERICAN REForm, 1890-1935 (1991); JANE ADDAMS, THE SOCIAL THOUGHT OF JANE ADDAMS (Christopher Lasch ed., 1965).

${ }_{52}$ At its most basic, social control is the desire of the elite and middle class to control the behavior of the poor and working class. Allen Davis writes that the social control thesis argues that reform movements are created by elite groups to seek control and manipulate the poor in order to create social stability and economic security that will benefit the elites. See DAVIS, supra note 10. Although settlement workers engaged in settlement work for a multitude of reasons, we must also recognize that social control played a large role. Settlement workers worried that the mass of new immigrants presented a real threat to the social order. Immigrant practices including drinking, dress, pre-marital sex, childrearing, and the ways in which leisure time was used all, at times, were seen as threatening. See LINDA GORDON, PITIED BUT NOT ENTITLED: SINGLE MOTHERS AND THE HISTORY OF WELFARE 43-44 (1994). Jerold Auerbach argues that even the provision of legal aid in the late nineteenth century was a form of social control. JEROLD AUERBACH, UNEQUAL JUSTICE: LAWYERS AND SOCIAL CHANGE IN MODERN AMERICA 55 (1976).

${ }_{53}$ For a discussion on lawyering and concepts of the public good in the early twentieth century, see Susan D. Carle, Re-Envisioning Models for Pro Bono Lawyering: Some Historical Reflections, 9 AM. U. J. GENDER SOC. POL'Y \& L. 81 (2001).

${ }_{54}$ Lillian Wald, Best Help to the Immigrant Through the Nurse (1907), microformed on Lillian Wald Papers, NYPL, Reel 24.
} 
American was not only to acknowledge the responsibility to obey the law and to have respect for the rule of law, but also to have access to the legal process and to assert legal rights. ${ }^{55}$

At least some settlement workers understood immigrants from Southern and Eastern Europe to have little understanding of the rule of law in a democracy. ${ }^{56}$ They essentially, and inconsistently, imagined that such immigrants were entirely lawless, or that they irrationally and slavishly followed religious law, and/or had come from regimes under which they had no legal rights and were subject to arbitrary government action. ${ }^{57}$ They understood that, because of immigrants' experiences in their former countries, they had learned to be suspicious, if not downright contemptuous, of government action and state officials. ${ }^{58}$ For example, one settlement worker wrote that "Hebrew" immigrants "did not fight authority, they simply agreed with it, and when it turned away did as they had done before." 59 This settlement worker understood this reaction as a mechanism learned in Russia to deal with unfair government action, but that it was inconsistent with American citizenship and democracy. ${ }^{60}$

Settlement workers believed that American justice was based upon the rule of law. Although often vague, at a minimum, the rule of law meant that government action was not arbitrary, that courts would treat similar cases alike, that state actors were themselves subject to law, and that the individual possessed certain rights that protected him against government action. ${ }^{61}$ Further, disputes between individuals were to be resolved through the court system, not through self-help. ${ }^{62}$

As settlement workers began to instruct immigrants on the rule of law, and became immersed in the neighborhood and courts, it became increasingly obvious that settlement workers' fantasies of the rule of law and American justice were often a far cry from reality. ${ }^{63}$ Such disconnects further fueled settlement workers' impulses for legal reform. ${ }^{64}$ Simultaneously, as we shall see, settlements advocated for and participated in the creation of a particularized and personalized justice. ${ }^{65}$ Such justice would be based on specific facts and an individual's life. ${ }^{66}$ Although settlement workers at the turn of the century did not see it as such, the type

\footnotetext{
ss See LINDA K. KeRBER, No CONSTITUTIONAL RIGHT TO BE LADIES 241-44 (1998) (discussing the obligations of citizenship and its relationship to gender).

${ }_{57}^{56}$ See e.g., LISSAK, supra note 35.

${ }^{57}$ See Frank H. McLean, An Experience in the Street Cleaning Department, in UNIV. SETTLEMENT SOC'Y, ANNUAL REPORT 1897 (1897).

${ }_{58}^{8}$ See id.

${ }^{59}$ Id.

${ }^{60}$ See id.

${ }^{61}$ Horwitz discusses the intellectual origins of the concept of the rule of law. See MORTON J. HORWITZ, THE TRANSFormation OF AMERICAN LAW, 1870-1960: THE CRISIS OF LEGal ORTHODOXY 226-30 (1992).

${ }^{6}$ See id.

${ }^{63}$ See infra Part V.

${ }^{64}$ See infra Part V.

${ }^{65}$ See infra Part V-VI. See also MichaEl WiLlRICH, CITY OF COURTS: SOCIALIZING JUSTICE IN PROGRESSIVE ERA CHICAGO (2003).

${ }^{66}$ See infra Part II.C.
} 
of law for which they advocated stood in tension with traditional understandings of the rule of law. As Morton Horwitz writes, there was a "fundamental conflict between a regime of formal and impersonal rules and one that sought to achieve substantive ends." $" 67$

\section{CONCEPTIONS OF KNOWLEDGE WithIN THE SETTLEMENT HOUSES}

The ways that settlement workers conceived of and sought to obtain knowledge directly relates to how they structured and carried out their legal projects. Settlement house workers perceived their knowledge to be based upon comprehending the neighborhood in which they lived, the specific problems it generated, and how the people of the neighborhood inhabited the city and lived their lives. ${ }^{68}$ Settlement house workers claimed to base their knowledge not only on seeing and inspecting the neighborhood, an ocular type of knowledge, but also on being part of the neighborhood and being in continual dialogue with those who lived in it. ${ }^{69}$ This type of knowledge was deeply experiential.

Although settlement houses engaged in a wide range of empirical studies, their expertise was not necessarily based on an objective scientific understanding. Rather, settlement workers' knowledge and expertise functioned on various levels. It was a methodology of participation, not just investigation, that combined subjective and objective knowledge grounded in understanding, empathy, participation, and investigation. ${ }^{9}$ Such knowledge was contextualized, relying on the specific and not the abstract, on observation, as well as personal relationships with neighbors. To explain the settlement workers' knowledge and the power derived from it, the head resident of College Settlement stated:

Sometimes the impressions of years of residence have been thought sufficient in bearing testimony; sometimes these have been strengthened by the collection of statistics or data bearing on the condition of neighborhood life at the moment in question. It has always been, however, the Settlement's first-hand knowledge which has been sought and which has given the value of its testimony. ${ }^{\text {T }}$

This language of observation, first-hand recollection, fact collection, and participation in neighborhood life appears repeatedly in the writings of

\footnotetext{
${ }^{67}$ HORWITZ, supra note 61 , at 229.

${ }^{68}$ See, e.g., WALD, supra note 18, at 261; see also COLLEGE SETTLEMENT ANNUAL REPORT 38 (1909).

${ }^{69}$ Mina Carson writes that settlement workers had an "intimate familiarity and local trust that belonged to a genuine inhabitant of the neighborhood." CARSON, supra note 9, at 66 .

${ }_{70}$ Later in the century, the empirical sciences would make a claim to a scientific-based objective knowledge. At the turn-of-the-century, however, the settlement houses prided themselves on possessing knowledge based upon sentiment and empirical data. On the social sciences and empiricism, see Thomas Haskell, The EMERgence of Professional SOCIal SCIENCE (1977); Dorothy RosS, ORIGINS OF AMERICAN SOCIAL SCIENCE (1990). On legal reform movements and the role of social science, see LAURA KalMAN, LEGal REALISM AT YALE, 1927-1960 (1986); JOHN HENRY SCHLEGEL, AMERICAN LEGAL REALISM AND EMPIRICAL SOCIAL SCIENCE (1995); G. Edward White, From Realism to Critical Legal Studies: A Truncated Intellectual History, 40 SW. L.J. 819 (1986).

${ }^{71}$ College SETTLEMENT ANNUAL REPORT 38 (1909).
} 
settlement house workers and structured their legal projects. ${ }^{72}$ Lillian Wald, founder and head resident of New York City's Henry Street Settlement, perfectly encapsulated the need for a law based on everyday reality and emphasized that this was part of the value that settlement houses added to law. She wrote, "Settlements have increasing authority because of the persistency of their interest in social welfare measures. They accumulate in their daily routine significant facts obtainable in no other way. Governors and legislators listen, and sooner or later act on representations of responsible advocates whose facts are current and trustworthy."73 Thus, everyday lives and on-the-ground facts directly impacted legislation and law. Settlement houses conducted the fact intensive surveys of how various laws functioned and the effects that they had on people's lives. Indeed, settlement workers understood the need for a living law-a law in actionbased on the material conditions of lives actually lived.

We might consider this a deeply feminized knowledge, based on daily experience that arose from the minute study of the life of a neighborhood, personal relationships, and acts of empathy. ${ }^{74}$ A College House Settlement worker wrote, "What we try to do is gain that intimate knowledge of the neighborhood and that sympathetic understanding of its life, which is the special offering every Settlement wishes to make to the public good." Leaders of the settlement house movement believed that through knowledge learned on the ground, they grasped what constituted the public good, and that the public good could be effectuated through various types of state action. As Mary Kingsbury Simkhovitch, founder of Greenwich House, wrote of the settlement houses, knowledge, and the state, "[I]n larger municipal matters, none have a greater opportunity to know things from the inside, to see what ought to be done, and to try to get it effected, than those living the daily life of a given quarter." knowledge, settlement house workers staked and defined their own

\footnotetext{
72 The language that settlement workers used regarding their aspirations and goals bears a striking resemblance to the language employed by some of the leading figures in the contemporary community justice movement. For example, Gerald P. Lopez writes of the Neighborhood Legal Needs and Resource Project that:
}

[b]y improving available problem solving (all problem solving-nonlegal and legal, in every imaginable combination) the Center aspires with others to enhance the capacity of those who live and work in these communities to satisfy basic needs, shape healthy relationships, and realize lofty aspirations. Together we seek to do so by fundamentally changing - a bit at a time, from the current blend of available resources-the institutional arrangements and practices that define markets, politics, and civic life. Chastened by the humility imposed by decades of experience, we mean nonetheless, through tenacious on-the-ground efforts, to help change both the current conditions and the future possible trajectories of social life.

Lopez, supra note 4 , at 76.

${ }^{73}$ WALD, supra note 18 , at 261.

${ }^{74}$ Carrie Menkel-Meadow writes that women lawyers reason "with an ethics of care and concern" and take "account of relationships and context rather than searching for abstract principles to solve legal problems." Carrie Menkel-Meadow, Exploring a Research Agenda of the Feminization of the Legal Profession: Theories of Gender and Social Change, 14 LAW \& SOC. INQUIRY 289, $312-13$ (1989). Whether or not Menkel-Meadow's account is presently accurate, it succinctly-although unintentionally-describes the attitude and methodology of many female settlement workers.

${ }^{75}$ COLLEGE SETTLEMENT SEVENTH ANNUAL REPORT 15 (1896).

${ }^{76}$ GREENWICH HOUSE ANNUAL REPORT 8 (1904). 
expertise. Settlement workers brought these methodologies and ways of knowing to their approach to law and legal reform.

As can be seen, gender is crucial to this story because it structured who provided and received legal services, who could exert expertise in particular subjects, how legal issues were framed, and who became state actors with particular types of power and authority. ${ }^{77}$ It also made immigrant and poor women the subject of intense scrutiny and state regulation, as middle-class women settlement workers were most easily able to claim power in those areas that involved women and children. As historian Robyn Muncy writes, "While creating their new professions in the Progressive era ... [middle-class] women discovered that their male counterparts were much more willing to cede professional territory, to acknowledge the female right to expertise in instances where women and children were the only clients. This encouraged creators of new female professions ... to define certain social problems in ways that made women and children central."

Furthermore, women settlement workers played a prominent role in functioning as a bridge between the lawyer and the laity, the professional and the client, the elite and the masses. We thus might label such women as "cultural brokers." As cultural brokers they brought legal knowledge to their neighbors and brought their neighbors legal needs to the attention of the state and more broadly the public. ${ }^{80}$ Such a role may have fit well with Victorian understandings of women as conciliators who could heal social divisions and animosities with care and comfort. ${ }^{81}$ Only by letting in women as legal actors and the settlements as legal sites can we fully understand turn-of-the-century urban legal culture. Yet, often women's contributions to law at the turn-of-the-century are categorized as social work rather than legal practice. This article seeks to blur such distinctions and categories, arguing that settlement house women practiced law under the rubric of social work. ${ }^{82}$ In the process, they created a novel form of legal practice.

\footnotetext{
77 See generally Susan D. Carle, Gender in the Construction of the Lawyer's Persona, 22 HARV. WOMEN'S L.J. 239 (1999) (reviewing KATHRYN KISH SKLAR, FLORENCE KELLEY AND THE NATION'S WORK: THE RISE OF WOMEN'S POLITICAL CULTURE, 1830-1900 (1995)) (discussing the role of gender in structuring the role of lawyers at the turn of the century). Joan Scott distinguishes between women's history and gender history. Where women's history might primarily be concerned with exploring women's lives, gender history asks how the socially constructed categories "man" and "woman" are created and maintained at particular moments in time. For Scott, gender is relational and is a principle way of signifying relationships of power. See Joan Scott, Gender as a Useful Category of Historical Analysis, 91 AM. HisT. REV. 1053, 1054, 1056, 1067 (1986).

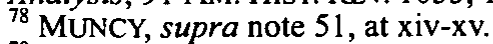

79 See Harvey Gee, A Review of Frank Wu's Renegotiating America's Multi-colored Lines, 5 N.Y. CITY L. REV. 203, 229 (2002) (describing a cultural broker as one who "bridge[s] [] linguistic, cultural, racial, and class gaps").

${ }^{80}$ One historian of settlement houses somewhat idealistically writes, "Through the settlement, the immigrant found a voice for his bewilderment concerning local regulations, access to the hospitals, the schools, and the courts." KRAUS, supra note 5, at 208.

${ }^{81}$ For an elucidation of this argument, see MUNCY, supra note 51 , at 21, 55.

82 On the development of social work and its deeply gendered origins, see LINDA GORDON, HEROES OF THEIR OWN LIVES: THE POLITICS AND HISTORY OF FAMILY VIOLENCE, BOSTON 1880-1960 (1988); REgINA KUNZEL, FALlEN WOMEN, PROBLEM GIRLS: UNMARRIED MOTHERS AND THE PROFESSIONALIZATION OF SOCIAL WORK, 1890-1945 (1993); DANIEL WALKOWITZ, WORKING WITH
} 


\section{SETTLEMENTS AND THE RISE OF SOCIOLOGICAL JURISPRUDENCE}

An analysis of law and the settlement houses also demonstrates how sociological jurisprudence, sometimes referred to as "progressive legal thought," was in part generated from the ground up by settlement workers immersing themselves in the quotidian legal issues of their neighborhoods and the city. Sociological jurisprudence stood in opposition to an understanding of law as abstract, formal, and removed from the realities of power disparities and economic inequalities. ${ }^{83}$ Sociological jurisprudence was concerned not with law on the books but with law in action and was especially enamored with collecting those facts which could expose the reality of how law functioned. ${ }^{84}$ In 1912, Roscoe Pound, credited with coining the term sociological jurisprudence, discussed its goals and premises. Pound wrote, "The main problem to which sociological jurists are addressing themselves today is to enable and to compel law-making, and also interpretation and application of legal rules, to take more account, and more intelligent account, of the social facts upon which law must proceed and to which it is to be applied."

Legal progressives called for the study of how government functioned, its affects on people's lives, the use of the social sciences and empirical data, the end of a "mechanical jurisprudence," and a new awareness of the importance of the "individualized application" of law. ${ }^{86}$ Oliver Wendell Holmes, Jr.'s famous statement that the life of the law has not been logic, but experience, was supported by the settlement houses of New York City, and elsewhere, that provided many of the facts, studies, and impressions

Class: SOCIAL WoRkeRs AND THE POLITICS OF MidDle ClaSS IDENTITY (1999). Susan Carle argues that women reformers with legal training sought to consciously present themselves as reformers rather than lawyers due to gender constraints. See generally Carle, supra note 77. Often women's roles as turn of the century legal actors are missed even within feminist legal scholarship. Martha Fineman writes that women reformers "had to rely on men as litigators and legislators to be the translators and transmitters of their views. This was a process fraught with peril; male legal actors such as Felix Frankfurter, comfortable with and in control of 'Law,' shaped and reshaped ideas with feminist orgins [sic] until they were no longer recognizable as such." MARTHA ALBERTSON FINEMAN, THE NEUTERED MOTHER, THE SEXUAL FAMILY AND OTHER TWENTIETH CENTURY TRAGEDIES 38 (1995). Likewise Christopher Tomlins recognizes the important role that women played in creating the welfare state in the early twentieth century. He, however, understands that they were social workers dependent upon male lawyers. Christopher Tomlins, Framing the Field of Law's Disciplinary Encounters: A Historical Narrative, 34 LAW \& SOC'Y REV. 911, 938-40 (2000). This Article attempts to demonstrate that at the turn-of-the century, there was considerably more fluidity between the disciplinary borders of social work and law, and that women functioned as legal translators and transmitters.

${ }^{83}$ See HORWITZ, supra note 61, at 187-89.

${ }^{84}$ See id.

${ }^{85}$ Roscoe Pound, The Scope and Purpose of Sociological Jurisprudence, 25 HARV. L. REV. 489, 512-13 (1912); see also Roscoe Pound, The Theory of Judicial Decision, 36 HARV. L. REV. 641, 660 (1923) (describing law as "a highly complex aggregate, arising socially from the attempt of men in politically organized society to satisfy the claims involved in civilized social life so far as they may be satisfied by a systematic ordering of conduct and adjustment of relations").

${ }^{86}$ Some of the best works on sociological jurisprudence include: BARBARA H. FRIED, THE PROGRessive ASSAULT ON LAISSEZ FAIRE: ROBERT HALE AND THE FIRST LAW AND ECONOMICS MOVEMENT (1998); N.E.H. HULl, ROSCOE POUND \& KaRL LleWEllyN: SEARCHING FOR AN AMERICAN JURISPRUdenCE (1997); Morton Horwitz, Progressive Legal Historiography, 63 OR. L. REV. 679 (1984); G. Edward White, From Sociological Jurisprudence to Realism: Jurisprudence and Social Change in Early Twentieth-Century America, 58 VA. L. REV. 999, 1006 (1972). 
that formed the basic knowledge for this new type of jurisprudence. ${ }^{87}$ Further, in many cases, it was women who led such studies. ${ }^{88}$ The importance of the connection between settlement houses and sociological jurisprudence cannot be overemphasized. The development of progressive legal thought was not wholly the work of professors within the ivied walls of Harvard and Yale and the hallowed halls of bar associations. It was also the product of the streets and urban environment. ${ }^{89}$ It is not solely, or even primarily, that Josephine Goldmark co-authored with Louis Brandeis the famous Supreme Court brief in Muller v. Oregon.$^{90}$ Rather, years before Muller, settlement houses conducted the fact intensive surveys of how various laws functioned and the effects that they had on people's lives. They then developed the legislation necessary to shape immigrants, industry, the city, the state, and the larger political economy of the nation. Indeed, settlement workers understood the need for a living law-a law in action-based on the material conditions of lives actually lived.

By the time legal progressives in law schools and the professional bar articulated such concepts, the practice of sociological jurisprudence had existed for over a decade and could be found in the settlement houses. For Pound and others to acknowledge this would have required them to recognize the significant role that elite and middle class women played in laying the groundwork for sociological jurisprudence. ${ }^{91}$ Instead, he and

87 Oliver WeNDEll Holmes, THE COMMON LAW 5 (Mark DeWolfe Howe ed., Harvard University Press 1963) (1881).

${ }^{88}$ See supra Part II.A.

${ }^{89}$ Roscoe Pound recognized the role the city played in creating a new form of jurisprudence and system of law. He wrote, "Demand for socialization of law, in America, has come almost wholly if not entirely from the city." Roscoe Pound, The Administration of Justice in the Modern City, 26 HARV. L. REV. 302, 311 (1913).

${ }_{90}$ Muller v. Oregon, 208 U.S. 412 (1908). In Muller, the U.S. Supreme Court upheld a maximum hours' law for women laundry workers. Id. at 423. The Goldmark and Brandeis brief on behalf of the National Consumer's League was filled with statistics regarding the harms women workers faced from overwork. Brief for the State of Oregon at 18-113, Muller v. Oregon, 208 U.S. 412 (1908) (No. 107). The brief primarily relied upon social and medical facts rather than legal argument or case law. See id. On Muller, see Anne Dailey, Lochner for Women, 74 TEX. L. REV. 1217 (1996) (arguing against Muller as representative of sociological jurisprudence); Sybil Lipschultz, Social Feminism and Legal Discourse: 1908-1923, 2 YALE J.L. \& FEMINISM 131 (1989) (discussing the Muller brief and its embrace of a particular type of feminism); Julie Nokov, Liberty, Protection, and Women's Work: Investigating the Boundaries between Public and Private, 21 LAW \& SOC. INQUIRY 857 (1996) (comparing courts differing treatment of labor legislation for men and women). On the National Consumers' League, see MAUD NATHAN, THE STORY OF AN EPOCH-MAKING MOVEMENT (1926) (providing a first person account of the early years of the NCL); LANDON R.Y. STORRS, CIVILIZING CAPITALISM: THE NATIONAL COMSUMERS' LeAGUE, WOMEN'S ACTIVISM, AND LABOR STANDARDS IN THE NEW DEAL ERA (2000) (discussing origins of the League and its role in lobbying for various labor laws).

91 Why many legal historians have neglected the role that settlements played in the creation of sociological jurisprudence remains a puzzle. For example, legal historian William Weicek in part credits populism and progressivism for a sustained attack on classical legal thought, yet does not discuss either the settlement houses or the role that women reformers played. Wiecek writes that the BrandeisGoldmark brief in Muller constituted "the first example of sociological jurisprudence in action." As this Article demonstrates, the settlement houses had been engaged in sociological jurisprudence for over a decade. See William M. WieceK, The LOST WORLD OF Classical Legal THOUGHT: LAW aND IDEOLOGY IN AMERICA 1886-1937, at 195 (1998). Part of the answer to the puzzle regarding legal scholars' neglect of settlement houses may reflect how law is defined as a discipline distinct from social work. Legal scholars might view the work of the settlement houses as social work rather than law. Yet observing such disciplinary borders is particularly ironic given that sociological jurisprudence called for a study of law in action and the need for law to meet social needs and promote social justice. Interestingly Felix Frankfurter at moments seemed to have given some credit to women for the legal 
many of the scholars who wrote of sociological jurisprudence neglected its settlement house roots, thus making it more elite and masculine than it was. In the process, the crucial role that women played in surveying and creating the path of the law was erased. ${ }^{92}$

With such a framework and understanding of the settlement houses, we can now turn to the concrete ways in which settlements interacted with law.

\section{PROVIDERS AND POPULARIZERS: THE DIRECT AND INDIRECT PROVISION OF LEGAL SERVICES AND INFORMATION}

The most straightforward and recognizable way in which settlements interacted with law was by providing direct legal advice to clients, and this Part begins with such a discussion. The direct provision of legal services, however, played a less significant role in settlement houses' legal interactions than the multitude of ways the settlements informally provided legal advice and knowledge to their neighbors. Settlement workers thus functioned as transmitters of law, spreading legal knowledge throughout the neighborhoods in which they worked and democratizing access to such knowledge. In the process, settlement workers hoped that knowledge of American law would further the Americanization of immigrants.

\section{A. FREE LEgAL COUNSEL}

The male-managed University Settlement of New York City ("University") was the first settlement house to provide free legal services. For many years, University also remained the settlement that was most concerned with imbuing a respect for law among its neighbors. University's leading status as a settlement steeped in law should be no surprise, for forty percent of its founding members were lawyers, and throughout its history, University attracted residents with legal training. ${ }^{93}$ Further, University, managed by men and housing male residents, had more direct access to New York's legal luminaries. Even so, women played a significant, although contested, role in providing legal aid. As Eastern law schools slowly opened their doors to women, female graduates had few opportunities to practice law and some began to forge their own uncharted

reforms they effectuated. Felix Frankfurter wrote of reformer and settlement house resident Florence Kelley that she "had probably the largest single share in shaping the social history of the United States in the first thirty years of this century." He further gave her credit for "securing legislation for the removal of the most glaring abuses or our hectic industrialization following the Civil War." Felix Frankfurter, Foreword to JOSEPHINE GOLDMARK, IMPATIENT CRUSADER: FLORENCE KELLEY'S LIFE STORY, at v (1953). For an excellent biography of Florence Kelley, see SKLAR, supra note 41.

${ }_{92}$ Michael Willrich's informative work situates the creation of sociological jurisprudence within the municipal courts of Chicago. He goes a long way in positioning sociological jurisprudence as less elite and arising within an urban context. Furthermore, he begins to credit the role that elite and middle-class women played. In contrast to this article, Willrich's analysis is intentionally court-centered and focuses mainly on developments after 1910. SeeWILLRICH, supra note 65.

${ }_{93}$ See KRAUS, supra note 5, at 63. 
careers as social reformers. ${ }^{94}$ Settlement houses provided fertile, if at times difficult, grounds for such women.

Sometime before 1899, Annette Fisk, a young attorney and graduate of New York University Law School, established an office at University Settlement and began to provide free legal assistance to neighbors. ${ }^{95}$ It was Fisk's idea to offer such services and the office was established on her own initiative. University did not pay her a salary, only giving her free use of a small office. Correspondence indicates that University permitted her to counsel only women. We may reasonably surmise that the types of cases that Fisk handled included domestic relations, evictions, and wage disputes. ${ }^{96}$ The fact that University limited her practice to women clients implies that University's management was uncomfortable with women practicing law. They would rather have neighborhood men go without legal assistance than subject them to a woman practitioner. University's reluctance further indicates that the type of gender segregation that occurred in the practice of law was instituted even in some of the most "progressive" organizations.

Concurrently with Fisk establishing her office, and perhaps due to the demand for Fisk's services, University, within months, pushed ahead with its plans and began contemplating establishing a branch of the Legal Aid Society within the settlement. ${ }^{97}$ They now offered a salary of $\$ 600$ (to be raised from contributors) to the attorney who filled the new legal aid position. Although University briefly considered Fisk for the position and

\footnotetext{
${ }^{94}$ Some Western and Mid-Western law schools had been open to women since the 1870 s. In 1870 , there were less than ten female attorneys practicing law in the country. There were seventy five in 1890 and over 1000 in 1900. See U.S. DEP'T OF THE INTERIOR BUREAU OF CENSUS, WOMEN IN GAINFUL OCCUPATIONS 1870-1970, at 42 (1979). In 1895, New York University School of Law began admitting women. Karen Berger Morello writes that many of the women who attended NYU law school sought a legal education in order to further engage in social reform activity. KAREN BERGER MORELLO, THE INVISIBLE BAR: THE WOMAN LAWYER IN AMERICA, 1638 TO THE PRESENT 83 (1986). See generally Phyllis Eckhaus, Restless Women: The Pioneering Alumnae of New York University School of Law, 66 N.Y.U. L. REV. 1996 (1991) (discussing the social activism of early women graduates from NYU). A number of female law school graduates worked in settlement houses. For example, Crystal Eastman worked in Greenwich Settlement while attending NYU Law School. See Sylvia A. Law, Crystal Eastman: NYU Law Graduate, 66 N.Y.U. L. REV. 1963, 1975, 1977 (1991). Likewise, Florence Kelley attended law school while working in Hull House in Chicago and later lived at Henry Street. See Carle, supra note 77 , at 253-54. On early women lawyers' education, careers, and reform activity, see VIRGINIA G. DRACHMAN, SISTERS IN LAW: WOMEN LAWYERS IN MODERN AMERICAN HISTORY (1998) (providing an excellent history of women lawyers in the United States, including their education and practice); VIRGINIA G. DRACHMAN, WOMEN LAWYERS AND THE ORIGINS OF PROFESSIONAL IDENTITY IN AMERICA: THE LETTERS OF THE EQUTTY CLUB, 1887 TO 1890 (1993) [hereinafter DRACHMAN, EQUITY CLUB] (discussing and reproducing letters of a correspondence club among women attorneys at the turn of the century); Barbara Allen Babcock, Women Defenders in the West, 1 NEV. L.J. 1 (2001) [hereinafter Babcock, Women Defenders] (discussing the careers of female defense attorneys in the $1890 \mathrm{~s}$ in the western states). As a number of legal scholars discuss, many of these early women lawyers were women's rights, temperance, and suffrage advocates. See generally Barbara Allen Babcock, Clara Shortridge Folz: Constitution Maker, 66 IND. L.J. 849 (1991) [hereinafter Babcock, Clara Shortridge Folz]; DRACHMAN, EQUITY CLUB, supra note 94; Lind, supra note 40.

${ }^{95}$ See Letter from James Reynolds to Mrs. William Gulliver, Records of University Settlement Society of New York City (Jan. 11, 1899), in THE JACOB S. EISENGER COLlECTION, Wisconsin Historical Society, Box 7.

${ }_{96}$ See id.

${ }^{97}$ See Letter from James Reynolds to Carl Schurz, Records of University Settlement Society of New York City (Jan. 10, 1899), in THE JACOB S. EISENGER COLLECTION, Wisconsin Historical Society, Box 7.
} 
Fisk had the support of some women contributors to the settlement, management preferred hiring a male attorney. University, however, was willing to allow Fisk to work without pay as an assistant to the new attorney. Management also suggested that the Women's Auxiliary of the settlement contribute funds for her salary if Fisk refused to work without pay. ${ }^{98}$ As the head resident, James Reynolds, wrote to one of Fisk's supporters, "[The Legal Aid Society] is quite willing to take Miss Fisk as an assistant to the Bureau, and thinks she might prove very helpful. She certainly would have the chance to get a great deal of practice, and if we are successful in finding the right sort of man that we want she will be able to learn a great deal from him." ${ }^{.99}$ As the letter demonstrated, although Fisk was a practicing attorney, University understood her proper role to be a male attorney's assistant.

In 1900, the Legal Aid Society established a branch at the settlement under the tutelage of a male attorney. ${ }^{100}$ Annette Fisk, in need of paid employment and undoubtedly insulted that University refused to pay for her services when it was willing to pay a male attorney, resigned. Although the discrimination that Fisk encountered demonstrates the extraordinary difficulties that female attorneys faced, it is nonetheless significant that Fisk, if only for a brief time, was able to forge a space for herself as an attorney within the settlement house. Further, it was she who recognized that settlement houses could provide direct legal aid to their neighbors and that such a need existed. Even more important for our inquiry, Fisk created a female space of lawyering in which a woman attorney provided legal aid to poor and working class women.

The clients of the University Settlement Legal Aid Branch (created after Fisk resigned and headed by a male attorney) were almost entirely immigrants. Workers who sought wage collections from their employers comprised the largest category of legal matters brought to the Legal Aid branch. ${ }^{101}$ In slightly over a year, the branch saw more than 2,500 clients, of whom 1,884 were men and 685 women. Of these cases, the vast majority settled out of court. ${ }^{102}$ The Legal Aid Society and University recognized that in many cases defendants did not have the means to pay any judgment. Thus, there was little that an attorney could do or that litigation would accomplish. ${ }^{103}$ Ironically, although the establishment of the branch was in part intended to demonstrate the efficacy and justice of American law, in practice it often proved law's inability to address wrongs. Without a defendant's ability to pay damages, often no legal remedy existed.

\footnotetext{
${ }^{98}$ See Letter from James Reynolds to Mrs. William Gulliver, Records of University Settlement Society of New York City (June 23, 1899), in THE JACOB S. EISENGER COLLECTION, Wisconsin Historical Society, Box 7.

${ }_{99}$ Letter from James Reynolds to Mrs. William Gulliver, Records of University Settlement Society of New York City (Apr. 27, 1899), in THE JACOB S. EISENGER COLLECTION, Wisconsin Historical Society, Box 7.

${ }^{100}$ See YeAR BoOK OF THE UNIVERSITY SETTLEMENT SOCIETY OF NEW YORK 46-50 (1900).

${ }^{101}$ See id. at 47.

${ }_{102}$ See id. at $47-48$

${ }^{103}$ See generally The University Settlement Branch of the Legal Aid Society, in YEAR BOOK OF THE UNIVERSITY SETTLEMENT OF NEW YORK 46 (1900).
} 
Perhaps this was one of the reasons why the branch closed, slightly over a year after it opened. Yet the fact that the branch saw over 2,500 clients demonstrates the extraordinary need that poor immigrants had for legal services. Even without an in-house branch, neighbors continued to seek legal advice and counsel at the settlement. After 1901, University referred neighbors to a variety of lawyers who provided pro bono or inexpensive services. One of these attorneys was Mary Quackenbos. Quackenbos, like Fisk, graduated from New York University Law School, worked at the Legal Aid Society, and in 1905 established the "People's Law Firm," which was dedicated to providing low cost legal services to the poor. ${ }^{104} \mathrm{Her}$ clients consisted not only of immigrants, but also of African Americans. Quackenbos worked closely with University Settlement, providing referrals, and at times giving financial assistance or work to clients, while she sought damages. ${ }^{105}$ Here, we see how University maintained a symbiotic relationship with direct legal providers. University's referrals to counsel and the settlement's willingness to provide material aid allowed poor immigrants to participate in the legal process. Further, this close relationship indicates a shift in policy by University Settlement regarding legal practice by women attorneys, away from a gender segregated policy to one that was more tolerant of women lawyers, especially those whose fees were nominal. It further points to the important role women attorneys played in providing legal services to the poor at the turn of the century.

\section{B. SPREADING LEGAL KNOWLEDGE}

Even more significant than the direct provision of legal services by settlement houses, was the rich array of informal legal knowledge, information, and advice that settlements provided as part of their day-today tasks. For instance, Greenwich settlement's description of its everyday goals stated that they worked in "patching up family differences, helping boys get jobs, seeing that truants go to school, reporting violations of the Tenement House Law ... [and] looking up legal points."107 Here the provision of legal services was part of the house's everyday activities, performed by those not necessarily formally trained as attorneys. Women settlement workers researched legal points, contacted city officials, and sought advice from professional lawyers.

Much of this informal legal activity occurred while workers accomplished other duties. Lillian Wald, founder of New York City's Henry Street Settlement (which was informally called the nurses' settlement), wrote, "No district nurse ... has not felt it incumbent upon herself to translate into elementary terms the laws that affect the welfare of the

\footnotetext{
${ }^{104}$ See Women Get Thieves After Police Give Up, N.Y. TIMES, Oct. 3, 1905, at 6.

${ }_{105}$ See New Field of Legal Work Among the Poor, N.Y. TIMES, June 11, 1905, at SM 7.

${ }^{106}$ See generally Babcock, Women Defenders, supra note 94; Babcock, Clara Shortridge Folz, supra note 94.

${ }^{107}$ Second Annual Report of Greenwich House 8 (1904).
} 
patients." ${ }^{108}$ She further emphasized that nurses could and should discuss "the laws that touch the people in their daily lives," and be able to explain the reasons for their enactment: "What greater value can an intelligent nurse have who going into the homes of the poor [has] knowledge of those laws, and can explain them to the family with whom she comes in contact?" 109 As can be seen in these statements, Wald refused to separate the disciplines of law and nursing-each was crucial to the well-being of a patient. Thus, she stressed the need for a holistic caregiving that transcended disciplines and sought to address all of a client's needs. We must also remember that Wald's nurses were all women and these women became legal communicators, translators, and educators. As nurses entered the space of their patients' homes, they brought with them a feminized, domesticated discourse of law.

Settlement houses' dissemination of legal knowledge took place in more formal settings as well. In 1895, for instance, University Settlement boasted that it "possessed a very complete set of books and pamphlets containing the body of municipal and State law in force in New York City." 110 These books were available to settlement house residents, workers, and neighbors who visited the house. University also established a number of groups where people could meet and discuss legal issues. In 1899, it created its first law club "as [sic] means of elevating legal standards of our quarter ... to bring together law students of this quarter and secure ... information ... beneficial to members." "Speakers during the first year included the District Attorney of New York City and a judge. Unfortunately the club left little documentation and no membership lists, making it impossible to know what the club did, and whether its membership extended to women.

In 1905, University formed a second law club, the Young Men's Law Association. The club was directed at involving young men interested in becoming attorneys in moot courts and in "studying the theory and practice of law." 12 The Association clearly saw the connection between law and citizenship, writing that its activities and discussions promoted "good citizenship." 113 Yet the club was open only to young men, again enshrining the practice of law as male and providing its male members access to the profession that young women lacked. Indeed, at least one aspect of the club was to introduce immigrant young men to prominent members of the profession who would explain their roles in the legal process. By 1910, the club announced that a number of its members had been admitted to the Bar

\footnotetext{
${ }^{108}$ Wald, supra note 54. (regarding the Henry Street Visiting Nurse Service, which was a cadre of nurses who would visit those who were poor and sick for a nominal fee or no fee at all); see also WALD, supra note 23, at 81-83 (discussing the need for, and sums paid to, visiting nurses).

${ }_{109}$ Wald, supra note 54.

${ }^{110}$ University Settlement Society, Report of the Years Work 21 (1895).

${ }^{111}$ Law Clubs, Records of University Settlement Society of New York City (1899), in THE JACOB S. EISENGER COLLECTION, Wisconsin Historical Society, Box 19.

${ }^{113}$ Semi-Annual Report of the Young Men's Law Association, Records of University Settlement Society of New York City (May 1910), in THE JACOB S. EISENGER COLLECTION, Wisconsin Historical Society, Box 19.
} 
and that these new attorneys would "bring the settlement spirit" into their work. $^{114}$

The club also sponsored a popular lecture series, open to the public, which drew neighborhood men and women. Although documents from its early years are missing, the lectures of 1909 , primarily given by attorneys, judges, and academics, included the subjects "Tact in Court," "Socialism and the Law," "the Municipal Courts," "the Relation of Law to Welfare," and the "History of the U.S. Constitution." 115 Such lectures, intended for an interested lay audience, indicate that the Association defined law broadly, searched for connections between law, social work, and social justice, and raised these connections and issues within a public forum. ${ }^{116}$

In addition to legal education occurring through personal contact and group discussions, some of the most popular publications of the settlement houses focused on legal issues. These publications were intended to spread and popularize legal knowledge. One of Greenwich Settlement's first major projects was the publication of The Tenants' Manual written by Emily Dinwiddie with the assistance of attorney Pauline Goldmark. The manual was "to serve as a handbook of information on sanitation, savings methods, legal matters, politics, education, and means of recreation," and was directed at neighbors and other settlement house workers. ${ }^{117}$ This document is remarkable in the breadth of its subjects and its succinct expositions of municipal law and regulation-areas that most closely affected the settlement houses and their neighbors. Further, the amount of effort put into the manual underscores the settlement house's recognition of the importance of law to the daily life of the neighborhood.

The Manual provided detailed information about regulations of the Department of Health, laws pertaining to adult and child labor, tenement house laws, and landlord/tenant relations. Included were instructions for reporting to the municipality vendors selling impure milk and other unwholesome foods. The manual explained how installment contracts functioned, what the compulsory education laws required, and how to bring claims for marital abandonment or a husband's non-payment of support. Interspersed with the discussion of laws and regulations was child care and housekeeping advice, including the optimum frequency for breastfeeding babies, formulas for creating cleaning solutions, the flushing and cleaning of bathroom appliances, the locations of playgrounds, and places to obtain free and pure milk. This manual, written by a woman, was to a large extent intended for other women, both settlement workers and tenement dwellers. Here law was embedded in the quotidian ways that the state regulated everyday interactions, from sending a child to school, to the placement of

\footnotetext{
${ }_{114}^{11} \mathrm{Id}$.

${ }^{115}$ Literary Meetings of the Young Men's Law Association, Records of University Settlement Society of New York City (1909-10), in THE JACOB S. EISENGER COLLECTION, Wisconsin Historical Society, Box 19.

${ }^{116}$ Semi-Annual Report of the Young Men's Law Association, Records of University Settlement Society of New York City (Mar. 11, 1910), in THE JACOB S. EISENGER COlleCtion, Wisconsin Historical Society, Box 19.

${ }^{117}$ Emily DinWIDdie, The Tenants' Manual (1903).
} 
garbage cans, to the purchase of household furniture and food. These were tasks for which women were responsible and that women encountered in their daily work and interactions. In contrast to any understanding that family and home life constituted a sphere separate from the state, the settlements grasped how the law regulated and asserted itself in the home and the daily life of the neighborhood-providing rights and regulating behavior. This was law brought indoors and domesticated-not in a theoretical way, but in a concrete manner that would be present in people's everyday existence. ${ }^{118}$ Furthermore, like Wald who refused to separate law from nursing, The Tenants' Manual took a holistic approach to law by integrating it into the fabric and minutiae of women's lives. This was sociological jurisprudence actuated and made real.

\section{MUNICIPAL ADMINISTRATION, POLICING, AND THE SETTLEMENT HOUSES}

\section{A. The StATE AND the SeTtLemENT Houses}

This Part explores the exceedingly close connection between settlement houses and municipal and state government. It argues that this relationship functioned to provide settlement workers, often women, with significant state power which could be asserted to control the poor and the working class. At the same time, settlement houses' work with government served to structure a new urban legal environment at the turn of the century that functioned to better at least some people's lives.

From their inception, New York City's settlement houses worked with city and state government and believed that collaboration with government could ameliorate, if not solve, some of the city's most severe problems. As settlements sought to define areas of concern and ultimately to pass regulatory laws, which they then participated in enforcing, settlement workers often became state or at least quasi-state employees. Such a situation allowed women settlement workers to gain unprecedented access to government and exercise significant state power. This Part explores material examples of how the settlements engaged in various investigations, prompting them to lobby for new regulations, the ways in which they policed neighborhoods in searching for legal infractions, and finally how settlements acted as legal intermediaries between neighbors and city government. As with other settlement activity, gender functioned on multiple levels.

\section{B. INVESTIGATION AND REGULATION}

Through their involvement with municipal and state governments, the settlement houses played a vital role in creating a new urban legal environment. This environment was marked by state regulation, an 118 For a discussion of how law functions in the quotidian, see HENDRICK HARTOG, MAN AND WIFE IN
AMERICA: A HISTORY (2000); Hendrick Hartog, Pigs and Positivism, 1985 WIS. L. REV. 899. 
expanded police power, an extension of social rights, and new forms of social control that brought opportunity and redress to neighborhoods while restricting freedom of private commercial enterprise and individual action. ${ }^{119}$ An analysis of the settlement houses' close interactions with city and state governments demonstrates how settlements combined and perceived as part of a legal continuum, inspection, reporting of violations, conducting of surveys, advocacy, and the enforcement of new laws.

For instance, Lillian Wald, Henry Street, and Union Settlement launched an investigation of immigrant women's use of midwives and immigrant midwives' qualifications. One settlement worker wrote of the investigation:

It was as the result of a particularly flagrant case of ignorance and neglect on the part of a midwife in her practice that the Settlement was moved to undertake this investigation... It was a woman close to the Settlement who was the victim of the particular midwife's incompetence. We realized that the foreign born women among our neighbors employed midwives as a result of agelong [sic] custom and we conjectured that in many cases these midwives were probably untrained and incompetent. ${ }^{120}$

As the committee found, the practice of midwifery was unregulated by the state. Thus, we see not only the settlements' penchant for immediate investigation of issues that it perceived to be problematic, but also a blanket dismissal of the competence of immigrant midwives on the basis that they were not professionally trained. ${ }^{121}$ We must equally be aware that the question of immigrant midwives' competence arose from the settlements' everyday interactions with neighborhood women. Yet, it was women settlement workers who had the power to identify and define immigrant midwives as a problem in need of a solution.

The settlements immediately established a committee to study immigrant midwives. The study revealed that there were 1000 midwives in Manhattan. Midwives attended $49 \%$ of Manhattan births, and $93 \%$ of Italian women used their services. The committee interviewed 800 midwives but found (according to what criteria is unclear) only $11 \%$ to be "excellent." 122

\footnotetext{
119 On the expanding use of state regulation in New York at the turn of the century, see Felice Batlan, $A$ Reevaluation of the New York Court of Appeals: The Home, the Market, and Labor 1885-1905, 27 LAW \& SOC. INQUIRY 489 (2002) (arguing that the New York Courts upheld police power regulations under the rubric of protecting the "de-commodified"' home). See generally Melvin Urofsky, State Courts and Protective Legislation During the Progressive Era: A Reevaluation, 72 J. AM. HIST. 61 (1985).

${ }_{120}^{120}$ ELLEN S. MARVIN, AS I REMEMBER UNION SETTLEMENT 31 (1940).

${ }_{121}$ On the history of midwife regulation in the United States, see generally RAYMOND DEVRIES, REgulating BIRTH: MidWives, Medicine, \& THE LAW (1985); DebORAH A. Sullivan \& Rose WEITZ, LABOR PAINS: MODERN MIDWIVES AND HOME BIRTH (1988); Stacey Tovino, American Midwifery Litigation and State Legislative Preferences for Physician-Controlled Childbirth, 11 CARDOZO WOMEN'S L.J. 61 (2004). These works understand that midwife regulation arose primarily from attempts by male doctors to monopolize the provision of health care. In this instance, however, it was progressive women reformers who proposed and lobbied for such regulation. Charlotte Borst provides an especially sensitive account of midwives, gender, ethnicity, and professionalism. Charlotte G. Borst, Catching Babies: The Professionalization of Childbirth, 1870-1920 (1995).

122 See Hearing on Midwives' Bill, N.Y. Times, May 13, 1907, at 4; see also MARVIN, supra note 120, at 31-32.
} 
Women settlement workers were able to position themselves as experts by virtue of their familiarity with the neighborhood, their class and gender, and their conclusions from the investigation. With facts in hand and the support of the Department of Health, a number of the settlement houses lobbied Albany for legislation to regulate midwifery. During legislative hearings, settlement workers testified, "[I]t was a menace to allow an army of midwives to ply their vocation without any inspection or regulation." 123 In 1907, New York State passed a law requiring that midwives be licensed by the Board of Health. ${ }^{124}$ As one Union worker wrote of the investigation and legislation: "This was a service initiated by the Settlement which had far-reaching effect and importance for the city as a whole ... It illustrates one value of the Settlement principle. It is because the resident is a resident, is a part of the neighborhood and in intimate touch with her neighbors that she is in a position where she can see life as her neighbors see it."

We must question, however, whether immigrant women had any independent interest in the state regulation of midwives. Was this a situation where local women called upon the settlement houses to complain of the practices of midwives after a neighborhood woman, perhaps a friend or acquaintance, had lost her life or that of her child through a midwife's fault? Perhaps settlement workers interpreted a neighborhood's grief and anger at a particular midwife to be an opportunity to call for regulation of immigrant women of whom they were already suspicious. As historian Linda Gordon writes in a different context, "Not only do problems create the need for problem solvers, but those who can define themselves as problem solvers are able to define what counts as a social problem."126 Here the settlements were able to delineate the problem (immigrant midwives), construct a role for themselves as investigators, and fashion a legal solution-a solution that brought them into even closer contact and cooperation with the state. Further, this was not a case of men imposing regulation upon women, but rather it was a campaign spearheaded by women settlement workers to impose state regulation on other women.

Underscoring the complex relationship between settlement houses and the state, Wald wrote that the greatest contribution of the Visiting Nurses Service and the settlements was that they "unified and harmonized ... those powers which aim at care and prevention, rather than ... punishment." 127 Yet in the regulation of midwives, Wald called directly on the state and its power to police and punish. The settlement houses undoubtedly reported violations of the midwife law. In doing so, Wald and those settlements involved, encouraged and partook in the state entering into one of the most intimate realms of a woman's life-childbirth. This initiative further brought immigrant women who acted as midwives under state control. Thus, the very conditions under which human reproduction occurred were now regulated by the state through the efforts of women

\footnotetext{
${ }^{123}$ See Hearing on Midwives'Bill, supra note 122.

${ }_{124}$ See MARVIN, supra note 120.

${ }_{126}^{125}$ MARVIN, supra note 120 , at 32 (emphasis in original).

${ }^{126}$ GORDON, supra note 52 , at 45.

127 WALD, supra note 18 , at 60.
} 
settlement workers. This is not to say that such regulation had no benefit or perhaps even saved lives. It does, however, underscore the settlements' use of law to police at least some immigrant women, in the name of protecting other immigrant women, and the settlements' close connection to the state in an area specific to women.

\section{SURVEILLANCE AND POLICING}

As the midwife legislation regulated women's bodies and professions in a deeply feminine area, settlement houses engaged in reporting violations of law to pertinent authorities. The settlements' day-to-day contact with neighbors, and the location of their houses within poor and immigrant communities, allowed them to function as the eyes of the state, placing neighbors and the urban environment under surveillance.

At times, settlement workers were apologetic and worked hard to justify their role in reporting and enforcing laws to themselves and to others. Greenwich House explained,

While we [at Greenwich House] do not propose to involve any individual family or person in any difficulty, we do feel that any information that we may be able to give will help toward better legislation or a better enforcement of existing legislation in regard to some of those fundamental things that most deeply affect the life of our tenement-house population, it is not only desirable, but absolutely incumbent upon us. ${ }^{128}$

Somewhat contradictorily, Simkhovitch later wrote:

We cannot give away our neighbors, we cannot get them into trouble, and yet we cannot be blind to the evils we see. But as a wise mother may overlook a wrongdoing from time to time in order to emphasize something more important when it comes up, so it is inhuman and unwise for a settlement to take over the office of law enforcement." 129

Yet settlement houses often did just that.

It is tempting to argue that Simkhovitch's statement imagined a more maternal state, engaged in caregiving, nurture, and forgiveness, not power and punishment. Such sentiments, however, rarely prevented settlements from participating in law enforcement, whether the settlement was run by men or women. The concept of maternalism in which middle class and elite women reformers saw themselves as mothers who provided help and sympathy to the poor but also exercised authority over those who required uplift, included the power to punish. As settlements' connections and cooperation with the state grew, punishment could take the form of the exercise of state power. ${ }^{130}$

\footnotetext{
${ }_{128}^{128}$ First Annual Report of Greenwich House 5 (1903).

129 SIMKHOVITCH, supra note 39 , at 101.

${ }^{130}$ Linda Gordon writes, "Maternalists imagined themselves in a motherly role toward the poor Viewing the poor as in need of moral and spiritual as well as economic help, middle-class women sometimes imagined giving that help as a mother to a child, combining sympathy with authority." GORDON, supra note 52, at 55 . On maternalism in a variety of contexts, see also THEDA SKOCPOL, Protecting Soldiers and Mothers: The Political ORIGINS OF SOCIAL POliCY IN THE UNITED STATES (1990); MOTHERS OF A NEW WORLD: MATERNALIST POLITICS AND THE ORIGINS OF WELFARE
} 
A clear example of this emerging linkage is University Settlement's Sanitary Union, established in 1895. ${ }^{91}$ The Union's activities included inspection of streets for cleanliness, enforcement of building ordinances, and observance and reporting of sanitary conditions in tenement houses. One University settlement worker and member of the Union, the aptly named Frank McLean, even obtained a temporary position with the Department of Street Cleaning where he became "a direct enforcer of the law." ${ }^{\text {"132 }}$ While taking his duties to uphold the law seriously, he also claimed that on the densely packed Lower East Side of New York City, where many poor and working class immigrants lived, convincing residents to comply with the law required "extra legal means." successful officer needed to exercise "discretion" in determining the best method of addressing each violation. ${ }^{134}$ McLean wrote of engaging in "sham" arrests, dumping garbage in yards, threatening "dire vengeance," and requiring individuals to pick up garbage in his presence. As he admitted, such tactics were almost "brutal" but necessary when immigrants "refused to obey the law."135 Thus, while attempting to teach the importance of observing the law, he and other officers used their state power to function outside of the law. Such contradictions reflected the settlements' complex relationship with the rule of law, where in the name of effective law enforcement, each case demanded an individualized solution. Yet such discretion, and what might be interpreted as arbitrary action, undermined the very lessons which the settlements sought to inculcate regarding the fairness, justice, and consistency of American law. Furthermore, the ways in which McLean carried out his duties were deeply gendered.

For example, in 1895, the Union made 922 complaints to city departments against housekeepers and tenants and only twenty-seven against city employees who failed to carry out their duties as street cleaners. ${ }^{136}$ This data indicates that the Union was more concerned with regulating women housekeepers in the tenement districts than with the city's male employees who were charged with removing garbage and cleaning streets. Other contemporary accounts, however, indicate that the

STATES (Seth Koven \& Sonya Michel eds., 1993); Naomi Cahn, The Power of Caretaking, 12 YALE J.L. \& FEMINISM 177, 191 (2000); Michael Grossberg, Balancing Acts: Crisis, Change, and Continuity in American Family Law, 1890-1990, 28 IND. L. REV. 273, 285-86 (1995).

${ }_{131}$ See McLean, supra note 57.

${ }^{132} I d$.

${ }^{133} \mathrm{Id}$.

${ }^{134}$ See id. The classic work discussing life on the Lower East Side of New York City for Eastern European immigrant Jews is IRVING HOWE, WORLD OF OUR FATHERS (1976). For a contemporary account of life on the Lower East Side, see HUTCHINS HAPGOOD, THE SPIRIT OF THE GHETTO (Harvard University Press 1967) (1909). See also HASIA R. DINER, LOWER EAST SIDE MEMORIES: A JEWISH PLACE IN AMERICA (2000) (providing a more complex discussion of who lived on the Lower East Side and the role of the neighborhood in Jewish imagination). Lillian Wald provided an illustrative description of the Lower East Side at the time, stating that "[t]wo decades ago the words 'East Side' called up a vague and alarming picture of something strange and alien: a vast crowded area, a foreign city within our own, for whose conditions we had no concern." WALD, supra note 18, at 2.

${ }_{136}^{135}$ McLean, supra note 57.

${ }^{136}$ See id. 
city's street cleaners were often extraordinarily derelict in their duties. ${ }^{137}$ Yet the Union concentrated on the domestic skills of women tenement dwellers. One Sanitary Union report discussed the significant failure of immigrant Jewish women, who lived in the tenement district, to separate their household garbage from ash in violation of city regulations. The report stated:

Next to proper methods of cooking, the need of ingenuity in the proper tenement-house kitchens, is the most pressing necessity ... That lack of ingenuity, that perverseness which knew no other way of separating ashes and garbage than by first mixing them ... is not hard to find. The husbands of tenement-house women saw them daily go through this extremely dirty and laborious process ... and they heard their complaints. They were made to believe that there was no other possible method of obeying the law, and many of them concluded that they would 'down' the administration that would enforce a law which would which would compel their wives to be scavengers. ${ }^{138}$

The male author of the report blamed immigrant wives for their ignorance, poor housekeeping skills, and failure to abide by the law. Further, the report situated the ash/refuse controversy squarely in the realm of politics, warning that men of the tenement districts would vote against the mayor under the incorrect, but honest, belief that the problem resided with the administration rather than with their wives' abysmal housekeeping skills. ${ }^{139}$ Jewish women's domestic failures and Jewish men's overdrawn desire to protect them against unjust laws perverted the election process. As University Settlement clarified, the problem was women housekeepers, not the law or male laborers of the street cleaning department, and the Sanitary Union did not hesitate to report their violations to city officials. Here, the settlement workers' perception of immigrant women's poor housekeeping skills made that perceived problem a matter of state concern. The practices of immigrant women housekeepers, like the work of immigrant midwives, was highlighted and policed by settlement house workers.

\section{SETTLEMENTS AS STATE INTERMEDIARIES}

Although the settlement houses' enforcement and policing efforts frequently turned against their neighbors, settlements also functioned as important intermediaries between the poor and government regarding the enforcement of city and state laws. Neighbors recognized this and used the settlements to report violations of law that the houses then would pass along to city or state government. In many instances, the settlement houses used their contacts to press the government into rectifying such violations, where complaints of poor immigrants would have otherwise been ignored.

137 See THE WOMAN's JouRNAL, Apr. 20, 1895, at 125; Ladies Health Association Plans, N.Y. TIMES, Apr. 3, 1895, at 3; see also Sara Monoson, The Lady and the Tiger: Women's Electoral Activism in New York City Before Suffrage, 2 J. WoMEN's HIST. 100, 124 (Fall 1990) (discussing Women's Municipal League campaign regarding street cleaning and the reporting of city workers).

${ }^{138}$ McLean, supra note 57 . Much like modem day recycling laws, city residents were expected to separate their garbage. Id.

${ }^{139}$ Id. 
In other instances, settlements were able to report violations without using residents' names, thereby protecting them from retribution. Greenwich House wrote, "To protest on behalf of the neighborhood became a habit and the neighbors realized that the Settlement could be counted on to growl where it was dangerous or at least inexpedient for the private citizen to voice a protest." ${ }^{40}$ Thus, in this context of protest when government services were not provided, settlement houses functioned as opponents of the municipality and the state.

This was particularly true regarding housing laws. Beginning in the mid- to late 1890 s, New York City's settlement houses provided a place where tenement dwellers could lodge complaints of tenement house violations, which settlement workers would then relay to city officials. The all-female College settlement saw one of its most important functions as "help[ing] towards the enforcement of the tenement house laws which make for better conditions of living." 141 In 1896, College Settlement discussed how a neighborhood father complained to a worker of conditions in the tenement where his family lived. The Settlement wrote: "It proved to be a matter of great importance in tenement-house hygiene, and the proper authorities took prompt measures ... The heads of the various departments of City Government realize that through our many friends we are likely to know points of value, and they are quick to listen to our suggestions.",142 Thus, settlement houses provided an important conduit through which women settlement workers claimed a voice in municipal administration while acting on behalf of their poor and working class neighbors.

Through the years, connections between city government and the settlements strengthened. University and Greenwich provided lodging for tenement house inspectors, a number of whom were women. By living in the settlement houses, and participating in their activities, the tenement inspectors became integrated into the community, witnessing housing conditions firsthand. ${ }^{143}$ Resident inspectors undoubtedly taught settlement workers about tenement laws and how to detect violations. These arrangements allowed for extremely close cooperation between the settlement houses and New York City's Tenement House Department. ${ }^{144}$ For example, a University Settlement report bluntly stated, "One of the five

${ }^{140}$ Sixth Annual Report of Greenwich House 5 (1907).

141 COLLEGE SETTLEMENT, SEVENTH ANNUAL REPORT 16 (1896). New York City first passed tenement regulations in 1867. By the late nineteenth century, the state of tenement houses had become a virtual obsession with a host of reformers. They claimed that crowded and dark tenement houses bred disease, crime and immorality. In 1900, there were over 80,000 tenements in New York City which housed a population of 2,373,070. See RoY LUBOVE, THE PROGRESSIVES AND THE SLUMS: TENEMENT HOUSE REFORM IN NEW YORK CITY 1890-1917, at 133 (1962). Jacob Riis famously wrote, "[I]n the tenements all the influences make for evil; because they are the hotbeds of the epidemics that carry death to rich and poor alike; the nurseries of pauperism and crime ... above all, they touch the family life with deadly moral contagion." JACOB RIIS, HOW THE OTHER HALF LIVES 2-3 (Harvard Univ. Press 1970) (1890). He went on to characterize the physical and social elements of tenements and their dwellers as possessing "reckless slovenliness, discontent, privation, ignorance . . . [and] dilapidation." Id. at 6 .

${ }_{42}$ COllege SeTtlement, SEVENTH ANNUAL REPORT 20 (1896).

${ }^{143}$ See e.g., Report of the Director of Greenwich House (June 2, 1905), microformed on Greenwich House Records, Tamiment, Reel 1.

${ }^{144}$ See generally LUBOVE, supra note 141 (providing history of New York's attempts to regulate tenement houses and the establishment of the Tenement House Department in 1903). 
inspectors for this district under the Tenement House Department will live in the house, so we may be brought into a close co-operation with the work of the Department." 45 With tenement house inspectors constantly available, settlements were able to exert strong influence over the Tenement House Department.

When Thomas Craine began his tenure as Tenement House Department commissioner in 1904, he quickly contacted settlement leaders. He wrote to University Settlement,

[I]t would be most agreeable to me to meet and know those engaged in Settlement Work in order that I may have from time to time the benefit of their friendship and advice and that efficient cooperation with the Department... I may be in a position to supplement your efforts and you are doubtless in a position to supplement mine..$^{146}$

The city came to the settlement houses for their expertise, recognizing the symbiotic relation between them and municipal government.

An additional material example of the close cooperation between the Tenement House Department and the settlements involved reporting landlords who failed to light hallways in violation of Section 82 of the Tenement House Act. ${ }^{147}$ The Department sent University Settlement fifty blank complaint forms and envelopes. University and the Department agreed that when a University worker discovered unlit hallways, he or she would complete a complaint and send it to the Department. ${ }^{148}$ Upon receipt of the first complaint, the Department would send a warning letter to the owner of the tenement house. ${ }^{149}$ After three complaints, the Department would transfer the case to New York City's corporation counsel's office for legal action. ${ }^{150}$ Thus, the Department depended upon the settlement house's investigations, assuming the veracity of any complaint it received, which then prompted departmental legal action without independent verification. In an environment in which the city simply did not have the resources to inspect all tenements and where residents of the tenements were at times hesitant to report landlords, settlement house workers, who in their daily routine walked the neighborhood, visited homes, and spoke to neighbors, proved to be critical resources.

In fact, settlement workers were constantly positioned to observe whether landlords were violating tenement house laws. For example, Greenwich House was involved intensely in reporting tenement house

\footnotetext{
${ }^{145}$ Report of the Headworker to the Council of the University Settlement, Records of University Settlement Society of New York City (May 19, 1902), in THE JACOB S. EISENGER COLLECTION, Wisconsin Historical Society, Box 3.

${ }^{146}$ Letter from Thomas Craine to Dr. Hamilton, Records of University Settlement Society of New York City (Jan. 28, 1904), in THE JACOB S. EISENGER COLLECTION, Wisconsin Historical Society, Box 9.

${ }^{147}$ Section 82 of the Tenement House Law required proper lighting in public hallways and stairs near the entrance and second floor from sunset to sunrise, and upon each of the other floors of a tenement house from sunset until 10:00 p.m. Tenement House Act, Section 53, Laws 1901, ch. 334.

${ }^{148}$ See Letter from Tenement House Department of the City of New York to Dr. Hamilton of University Settlement, Records of the University Settlement Society of New York City (Apr. 9, 1904), in THE JACOB S. EISENGER COLLECTION, Wisconsin Historical Society, Box 9.

${ }^{149}$ See id.

${ }^{150}$ See id.
} 
violations and lobbying the Tenement House Department for specific results. ${ }^{151}$ In 1905, Greenwich residents Miss Herzfeld and Miss Henderson conducted an investigation of the standard of living of residents in the Greenwich Village area. ${ }^{152}$ While engaged in this house-to-house survey, they uncovered many tenement house violations, which Greenwich promptly reported to the Tenement House Department. ${ }^{153}$ Greenwich wrote that the Department quickly took legal action resulting in "sanitary improvements." ${ }^{154}$ By 1906, Greenwich began lobbying the Tenement House Department to condemn and destroy numerous tenements that they believed to be beyond repair. ${ }^{155}$ The settlement also created a system to record all reports that Greenwich made to the state and the city, and the actions taken by officials in response. ${ }^{156}$ With such a system, Greenwich could put continual pressure upon officials to respond to their complaints and concerns.

The settlement houses' efforts regarding tenements were not limited to inspection and enforcement; they also played a vital role in preventing amendments that would weaken the tenement house laws. As such they were powerful lobbyists. After passage by New York State of the 1901 Tenement House Law, property owners vigorously sought to repeal or amend its most important sections. ${ }^{157}$ Working together in organized campaigns, New York's settlement houses launched massive efforts to prevent any changes. ${ }^{158}$ In 1903 and again in 1906, legislation was introduced into the New York State Assembly that would have changed the definition of a tenement house from one with three or more apartments to one with over three apartments. ${ }^{159}$ Various other bills would have repealed many of the most significant provisions of the Tenement House Act, including requirements for light, air shafts, and indoor plumbing. ${ }^{160}$

\footnotetext{
${ }^{151}$ See e.g., Report of the Director of Greenwich House (Jan. 19, 1905), microformed on The Greenwich House Records, Tamiment 139, Box 1, Folder 18, Tamiment Library/Robert F. Wagner Labor Archives (New York Univ.).

${ }_{152}$ See id.

${ }_{154}^{153}$ See id.

${ }_{154}^{15}$ See id.

${ }^{155}$ See id.

${ }^{156}$ See id.

${ }^{157}$ The Tenement House Law of 1901 was ground breaking legislation. In part, the law required the installation of flush toilets for every two families, air shafts, certain fireproofing, fire escapes, and set forth minimum requirements regarding light, ventilation, and square footage. See LUBOVE, supra note 141 , at 134-35. Historian Morton Keller writes that " $[\mathrm{t}]$ his 'new law' code of 1901 served as a model for a multitude of other state[s]." MORTON KELLER, REgUlating A NEW ECONOMY: PUBLIC POLICY AND ECONOMIC CHANGE IN AMERICA, 1900-1933, at 174 (1990). The 1901 law emerged from an in depth investigation and study by the Tenement House Commission. The findings of the Commission were published in a book. See RoBERT W. DEForest \& LAWRENCE VEILLER, THE TENEMENT HOUSE PROBLEM (1900), reprinted in THE TENEMENT HOUSE PROBLEM, INCLUDING THE REPORT OF THE NEW YORK STATE TENEMENT HOUSE COMMISSION OF 1900, at 3 (Robert W. De Forest \& Lawrence Veiller eds., 1903). In 1904, the New York Court of Appeals upheld the constitutionality of the Act. See Tenement House Dep't of New York v. Moeschen, 179 N.Y. 325 (1904), aff'd, 203 U.S. 583 (1906).

${ }^{158}$ See, e.g., Report of the Directors of Greenwich House (Feb. 14, 1906), microformed on The Greenwich House Records, Tamiment 139, Box 1, Folder 19, Tamiment Library/Robert F. Wagner Labor Archives (New York Univ.).

${ }_{159}$ See The Association of Neighborhood Workers, Attack on Tenement House Reform (Feb. 16, 1903), microformed on The Greenwich House Records, Tamiment 139, Box 29, Folder 9, Tamiment Library/Robert F. Wagner Labor Archives (New York Univ.).

${ }^{160}$ See id.
} 
Greenwich House led the opposition to the bills. ${ }^{161}$ As Simkhovitch wrote, the amendments would entirely remove "from the scope of the Tenement House Act and the jurisdiction of the Tenement House Department over 22,000 there-family [sic] houses in Greater New York. If the bill becomes law, it will result in stopping the work of cutting windows for the dark, tuberculosis-breeding rooms ... or removing the unspeakably vile school sinks." 162

In these campaigns, women settlement workers often took the lead in lobbying Albany. ${ }^{163}$ They claimed that they were speaking on behalf of the entire neighborhood and that they possessed a special expertise on the tenement house problem that derived from their residency and work in the tenement house districts. In a letter to the New York State governor and legislature, Greenwich wrote, "The members of the Society believe that through the settlement ... it has special opportunities for ascertaining and understanding the needs of the tenement house population."164 Some settlement workers claimed that they gave voice to otherwise voiceless immigrant women of the neighborhood. Lillian Wald wrote, "When I first went to the East Side I would always ask the opinion of the mothers of the neighborhood before going to Albany to try to get our bills passed. Timidly and backwardly they would give us their ideas." ${ }^{165}$ On a widely distributed flier opposing the amendment of the tenement house laws, five of the seven signers were women. ${ }^{166}$ In the first years of the twentieth century, women settlement leaders, using the settlements as an institutional forum, made the work of preservation of the tenement laws deeply, although not entirely, feminized. Yet, the settlement leaders did not base their authority on being women, on maternalism, or on a natural insight into the domestic. ${ }^{167}$ Rather, they made clear that it was founded on an expertise gained through knowledge of the tenement house districts, those who lived there, and contacts that the settlements formed with city and state officials.

In connection with the tenement house laws, the settlements created an institutional space not only for women settlement workers to become immersed in political activity, but also, in the best tradition of settlement houses, for various inter-class alliances to form. Henry Moskowitz, a Jewish immigrant, former tenement dweller, and settlement house worker, began organizing tenant unions that joined the settlement campaign to protest any amendment to the law. ${ }^{168}$ One of the first unions, the East Side Civic Club, working from Madison Settlement, gained the support and

${ }^{161}$ See Report of the Directors of Greenwich House, supra note 158.

162 Id. School sinks were outhouses that did not flush. Rather, matter would accumulate in the bowl. A valve would then be opened that allowed water to rush in. Some school sinks were not cleaned for weeks at a time. See Batlan, supra note 119, at 503-04.

${ }^{163}$ See The Association of Neighborhood Workers, supra note 159.

164 Letter from Greenwich House to the Governor and Senate and Assembly Cities Committee (Feb. 12, 1903), microformed on The Greenwich House Records, Tamiment 139, Box 29, Folder 9, Tamiment Library/Robert F. Wagner Labor Archives (New York Univ.).

${ }_{165}^{16}$ Stanley Garten, A Great Jewess-Lillian D. Wald, SYNAGOGUE LigHT, Apr. 1937, at 2, 3.

${ }_{166}$ See The Association of Neighborhood Workers, supra note 159.

${ }_{167}^{167}$ On maternalism, see sources cited supra note 130 .

168 On the life of Henry Moskowitz, see generally ELISABETH ISRAELS PERRY, BELLE MOSKOWITZ: FEMININE POLITICS AND THE EXERCISE OF POWER IN THE AGE OF ALFRED E. SMITH (1992). 
participation of the Socialist Party. ${ }^{169}$ Mary Simkhovitch claimed this was the first time that the Socialist Party in New York took an interest in municipal issues. ${ }^{170}$ Together, the settlement houses, various clubs, tenant unions, and the Socialist Party gathered 20,000 signatures against any amendment to the law, and presented their petition in Albany. ${ }^{171}$ This interclass coalition of men and women was repeatedly able to claim victory in preserving the tenement house law.

As this Part has demonstrated, the settlement houses forged extraordinarily close ties with municipal government. They used these ties and contacts in a multitude of ways. At times they proposed and lobbied for legislation, at other times they reported violations, and at certain moments they sought to exercise state power and to enforce the law. Thus, the settlement houses' relationship to questions of social control is complex and multi-faceted. Certainly, many of the laws for which the settlements advocated and enforced made life better, more comfortable, and cleaner for at least some neighbors. We can see this in connection with tenement house laws under which neighbors continually and consistently lodged complaints with settlement houses seeking enforcement of what they understood to be the law. ${ }^{172}$ Settlement houses were often able to lend weight to these complaints that arose from daily life. Yet, even here, settlement houses exerted social control and ultimately, state power over landlords. ${ }^{173}$ In other cases, however, neighbors, especially immigrant women, were subjected to tremendous pressure by settlement house workers to conform to a variety of bourgeois norms, such as maintaining and cleaning homes and sidewalks in a manner deemed acceptable by settlement workers now armed with state power.

\section{THE SETTLEMENT HOUSES AS LEGAL REFORMERS: THE CASE OF INSTALLMENT CONTRACTS}

The settlement houses' legal methodology, as exemplified in the case of midwife legislation discussed above, often proceeded by identifying a problem, conducting an investigation, and then seeking legal reform. As argued, such reforms often sought to regulate immigrants' behavior while simultaneously attempting to imbue a respect for American law. In this Part, we study another iteration of this dynamic. In 1902, University Settlement conducted a major investigation of installment contracts on the Lower East Side of New York and the legal proceedings and interactions generated by these contracts. ${ }^{174}$ The study was conducted by University

169 See SIMKHOVITCH, supra note 39 , at 75-76.

${ }^{170}$ Id.

${ }^{171} I d$.

${ }^{172}$ See Felice Batlan, Gender in the Path of the Law: Public Bodies and the Politics of Reform in Late Nineteenth-Century New York City (Jan. 2005) (unpublished Ph.D. dissertation, New York University) (on file with Bobst Library, New York University).

${ }^{173}$ As Jared Day has written, many tenement landlords were themselves immigrants, often with small real estate holdings. See JARED N. DAY, URBAN CASTLES: TENEMENT HousING AND LANDLORD ACTIVISM IN NEW YORK CITY, 1890-1943, at 31-34 (1999).

${ }_{174}$ Henry R. Mussey, a graduate of Columbia University, headed the study. Other members of the committee included W. Kirkpatrick Brice, Samuel Thorne, Jr., and Henry Taft. The "Fake" Installment 
under the direction of Henry Mussey, with Rosalie Loew, head attorney at the Legal Aid Society, participating in the investigative work and legal analysis. ${ }^{175}$ Unlike some of the other investigations conducted by settlement houses, which primarily focused on individual behavior rather than on how institutions functioned, here, the settlement turned its attention to law and the legal process, seeking to reform and control immigrant practices, and also to the legal process surrounding installment contracts. Through an examination of the installment contract investigation, we can also observe how settlements understood law as part of the larger social and political economy. For the settlement houses, law could not be divorced from social conditions.

Installment contracts involved the sale of goods, pursuant to which the purchaser would pay the sale price on a weekly or monthly basis. Under these contracts, title to the property remained with the vendor until the full purchase price was paid. ${ }^{176}$ New York law permitted the vendor, in cases of default, to recover the property without remitting to the purchaser any portion of the price already paid. ${ }^{177}$ If the property was not returned, the vendor could begin an action for conversion, and the debtor could be imprisoned. ${ }^{178}$ One widely used written installment contract was a legally sophisticated document which stated that title to the property remained in the vendor until receipt of full payment. ${ }^{179}$ Upon non-payment, the purchaser was to surrender the goods. ${ }^{80}$ The contract further granted the vendor access to the purchaser's home to seize goods while waiving any claim of trespass by the purchaser against the vendor. ${ }^{181}$

As part of its investigation of installment contracts and the judicial process surrounding them, settlement workers interviewed storeowners, consumers, city marshals, court officials, attorneys, charity workers, and legal organizations. ${ }^{182}$ They also examined a variety of court records and

Business (1903), reprinted in UNIVERSITY SETTLEMENT SOCIETY OF NEW YORK CITY PAPERS, at 39-40 (Russel Sage Foundation 1936).

$7{ }^{75}$ See To the Committee of the Council of the University Settlement, Records of the University Settlement Society of New York City (Fall 1902), in THE JACOB S. EISENGER COLLECTION, Wisconsin Historical Society 1-2, Box 8. In 1895, Rosalie Loew, the daughter of Jewish-Hungarian immigrants, graduated from New York University Law School and entered her father's law practice. She joined the Legal Aid Society of New York City in 1897, where she practiced matrimonial, civil, and criminal law and had an active court practice. In 1901, she was appointed by the Society to the position of General Attomey and held this position until 1905, when she resigned to form a law practice with her new husband. Later in the century, Loew campaigned for women's suffrage, and served as a state and municipal official. She eventually was appointed by Mayor Fiorello LaGuardia to a judgeship in the domestic relations court. Little scholarship exists about Loew or her role at the Society. See generally Rada Blumkin, Rosalie Loew Whitney: The Early Years as Advocate for the Poor, in WOMEN'S LEGAL HISTORY BIOGRAPHY PROJECT (2001),

http:/www.law.stanford.edu/library/wlhbp/papers0203/rblumkin-WhitneyF01.pdf; Danielle HaasLaursen, Rosalie Loew Whitney: Lawyer, Crime Fighter, Judge, Political Activist, and Suffragist, in WOMEN'S LEGAL HISTORY BIOGRAPHY PROJECT (2001),

http://www.law.stanford.edu/library/wlhbp/papers/RLW.pdf.

${ }_{176}$ See The "Fake" Installment Business, supra note 174, at 11.

177 Id.

${ }^{178} \mathrm{Id}$.

${ }^{179} I d$.

${ }^{180} \mathrm{Id}$.

${ }^{181}$ Id. at $39-40$.

${ }^{182}$ Id. 
attended court proceedings. ${ }^{183}$ Thus, this study was immensely concerned with all aspects of the business and law surrounding such contracts, including who entered into them, how the legal process functioned, how contracts were enforced by individual merchants, and what occurred in court.

Installment plans were so popular on the Lower East Side and merchants so readily extended credit that a large part of the trade in furnishings, sewing machines, carpets, bedding, books, jewelry, clothing, and pianos was conducted on an installment basis. ${ }^{184}$ Large merchants, such as the various department stores and Singer Sewing Machine, sold on installment, as did the small stores and peddlers that lined the streets of the Lower East Side. ${ }^{185}$ Over one-sixth of all cases brought in the municipal courts on the East Side involved installment contracts. ${ }^{186}$

At times, the investigation found that heavy handedness and fraud were rampant. The University report charged:

The cases of injustice and serious loss to the poor, through installment sales, have been all too common everywhere, yet nowhere else, so far as can be learned, has there been the systematic sale of worthless goods at high prices, and systemic imprisonment for debt and no debt, the systematic corruption of public officials and courts that has made the installment business a hissing and a by-word all over the East Side of New York. ${ }^{187}$

The report charged that such corruption was due to the unique combination of "legal and social conditions that prevail in New York." 188 Again, settlement workers refused to separate the social and the legal. To understand the role that courts played in enforcing these contracts, one had to recognize the social and economic conditions surrounding them.

The report delineated different strata of the installment business, finding that large merchants extended credit only to steady wage earners and rarely foreclosed on property, instead extending payment schedules. ${ }^{189}$ The major merchants, however, refused to provide credit to the poor. ${ }^{190}$ The poor bought goods on installment from small shops and peddlers who either carried their wares with them or were "pullers-in." customers on the streets and in their homes, and brought them into the stores where they worked. ${ }^{192}$ Further, salesmen sold sewing machines by going from house to house. ${ }^{193} \mathrm{~A}$ machine valued at $\$ 25$ to $\$ 35$ required a down payment of $\$ 1$ and weekly installments of fifty cents. ${ }^{194}$ The report

${ }^{183} I d$. at 7 .

${ }^{184}$ Id. at 9 .

${ }^{185}$ Id. at 10

${ }^{186}$ Id. at 24.

${ }^{187}$ Id. at 10 .

${ }^{188}$ Id. at 10 .

${ }^{189}$ Id. at $12-13$.

${ }_{190}^{190}$ Id. at 12.

191 Id. at 15 .

192 Id. at $15-16$.

${ }^{193}$ Id. at 40. 
stated that purchasers of these machines were primarily poor tailors and women who worked in their homes. ${ }^{195}$ Defaults on sewing machines were common and the report criticized salesmen for their inflated prices and their "altogether too great persuasive powers." 196 Yet it was the merchants of faux "luxury goods" such as jewelry, watches, and clocks whom the report rebuked most severely. ${ }^{197}$ These vendors, the report claimed, would immediately begin legal process when a purchaser missed a single payment.

Pullers, peddlers, and small merchants were mostly Eastern European Jews, and the report incessantly described their ignorance, poverty, and lack of morality. ${ }^{199}$ Yet even some peddlers used written contracts. ${ }^{200}$ One such peddler's agreement read: "The undermentioned [sic] goods are to be returned, or specified prices paid to consignor on demand. The title to the goods, or to proceeds if sold, to the amount of specified prices, is in the Consignor until they render a bill of sale., ${ }^{201}$ Thus, even peddlers possessed a degree of legal knowledge and sophistication. In contrast to University's portrayal of peddlers as ignorant, it appears that they had a keen knowledge of American law and the credit system. Belying its own accusation of ignorance and lawlessness, the report stated that peddlers and small merchants, "invoke[d] the law far more frequently" than larger establishments. ${ }^{202}$ Ironically, the settlements understood that part of citizenship - becoming American - was knowledge of, and respect for, law and its uses. Here, however, they condemned the immigrant who actually used and relied upon legal process.

As in so many of the settlements' interactions with law, issues of gender permeated the report's analysis of installment contracts. For example, the University report emphasized that almost any household good could be purchased on installment. ${ }^{203}$ One advertisement read: "Dealer in Cloaks, Clothing, Rugs, Extension Springs, Wringers, Albums, Lace, and Chenille Curtains, Table Covers, Furniture, Jewelry, Pictures, ect [sic]. Weekly or monthly payments taken."204 Thus, the installment business intimately implicated the domestic; salesmen and peddlers entered homes to sell goods that would furnish homes. As purchasers executed installment contracts, the home became a legal site where commercial contracts were signed and enforced. The report unsurprisingly found that housewares were primarily purchased on installment by women and it claimed that Italian immigrant women were targeted by peddlers for "their ignorance of the law

\footnotetext{
${ }^{195}$ Id.

${ }^{196}$ Id. at 41 .

${ }^{197}$ Id. at $18-24$.

${ }^{198}$ Id. at 23-24.

$199 \mathrm{Id}$. at 16.

${ }^{200} I d$. at 43.

${ }^{201} \mathrm{Id}$.

${ }^{202} \mathrm{Id}$. at 41.

${ }^{203} \mathrm{Id}$. at 42.

${ }^{204}$ Id.
} 
and love of jewelry."205 It asserted that wives entered into installment contracts while husbands were absent, leaving them vulnerable to the persuasive powers and tricks of male peddlers and store keepers. ${ }^{206}$ Indeed a wife customarily signed installment contracts in her husband's name, making him responsible for the debt. ${ }^{207}$ The report claimed, "Husbands are habitually arrested on contracts made by their wives."208

Describing the results of men's arrest for non-payment of debt on contracts entered into by their wives, the report emphasized the onerous impact and trauma that immigrant families suffered as city marshals arrested men in their homes. ${ }^{209}$ For example, the Italian immigrant wife of one arrested man refused to leave his side as city marshals dragged him from his home to jail. ${ }^{210}$ She purportedly sobbed, "I no go without my man ... I have three babies. I no stay alone. Please letta my man out?"211 The report continued, "[T] he baby opened its blue eyes and, seeing its mother sobbing, began to cry also." 12 Although the facts are unclear, it appears that the wife had purchased a watch for $\$ 75$, believing that it was gold, only to find that it was worth less than $\$ 10 .{ }^{213}$ Thus, pushy peddlers and naïve wives together perverted the legal process, throwing homes into chaos.

As discussed in the report, the installment business turned capitalism, contracts, and the legal system on their heads. The report alleged that purchasers who signed installment contracts often were illiterate, and naively relied upon wily vendors to explain a contract's terms. ${ }^{214}$ Some vendors would erase terms in executed contracts, substituting more onerous provisions. ${ }^{215}$ Going to the heart of the installment business, the report further claimed that the primary purpose of many of these contracts was to provoke default and imprisonment. ${ }^{216}$ As men were arrested, the vendor demanded additional payments, and the return of merchandise, before agreeing to drop the lawsuit. ${ }^{217}$ City marshals, paid by vendors for service of process, often purposely failed to deliver summonses, hastily arrested people, and received large fees. ${ }^{218}$ Thus, the report contended, the installment business was seeped in corruption. Even without blatant

\footnotetext{
${ }^{205}$ Id at 18-19. On immigrant women's desire for consumer goods, see EWEN, supra note 6; KATHY PEISS, CHEAP AMUSEMENTS: WORKING WOMEN AND LEISURE IN TURN-OF-THE-CENTURY NEW YORK (1986). On creating a home through market purchases, see GWENDOLYN WRIGHT, MORALISM AND THE MODEL HOME: DOMESTIC ARCHITECTURE AND CULTURAL CONFLICT IN CHICAGO, 1873-1913 (1980). 206 The "Fake" Installment Business, supra note 174, at 18-19.

${ }^{207} \mathrm{Id}$.

${ }^{208} \mathrm{Id}$. at 28

$209 \mathrm{Id}$. at $20-21$.

${ }^{210} \mathrm{Id}$.

211 Id. at 21 .

212 Id. at $21-22$.

${ }^{213}$ Id. at $22-23$.

${ }^{214} \mathrm{Id}$. at $22-23$.

$215 \mathrm{Id}$. at 22.

${ }^{216} \mathrm{Id}$. at 23 .

${ }^{217} I d$. at $23-24$

${ }^{218}$ On Progressives' efforts to abolish the age old practice of litigants paying fees to justices of the peace, see WILLRICH, supra note 55, at 20-23. On the Legal Aid Society's efforts to combat arrests for defaults under installment contracts, see MAGUIRE, supra note 2, at 108-12.
} 
corruption, the report asserted that an immigrant debtor who actually received notice of the default action faced little chance of success in court. $^{219}$ As it recognized, "A frightened foreigner, ignorant of language, law, customs, without counsel, is pitted against a more or less shrewd dealer, familiar with the ins and outs of legal practice, acquainted with judge [sic] in many cases, and represented by competent legal counsel.",220 Although subtle, the report insinuated that even judges failed to be impartial. ${ }^{221}$

The report was an indictment, not only of the installment business, but also of the law and courts, which partially created the environment in which installment contracts could flourish. Indeed, the cover page of the report displayed Percy Shelley's quote, "Where law is made the slave of wrong." 222 Unlike many of the settlements' other legal endeavors, which showed an undying faith in the power of law and the ability of state action to cure wrongs, with the installment contract investigation the settlement understood that law and the court system created conditions of exploitation rather than justice and redress.

As discussed throughout this Article, the settlement houses believed that the transformation of immigrants into citizens required a respect for American law and a belief in the rule of law. Installment contract abuses generated a distrust and lack of respect by the immigrant for American law and courts. As University's pamphlet stated, installment contracts bred "hatred for law among a class of people who especially need respect for law, but who are compelled to look upon it as made for oppression rather than for the defense of the poor and weak.",223 The installment business and the legal process surrounding it taught the wrong lessons regarding American law.

The settlement's pamphlet on installment contracts recommended legislation to prevent the sale of "luxury" items, including watches, jewelry, and ornamental goods to "socially undeveloped people" who could not "take care of themselves." 224 In the authors" view, poverty negated one's judgment and ability to participate in the marketplace. Poor immigrants' - especially poor women's-desire for the consumer goods that American capitalism offered became a character flaw requiring state intervention. Law would intervene where character, the market, and a husband's ability to protect and control his wife failed. The report declared, "[C]ompetition has stretched credit to the breaking point. Unlimited and unregulated credit, working under conditions of general ignorance, poverty, and small moral development on the one side, and hardly less ignorance on the other ... must always work havoc." 225 Such suggested reforms once again functioned to control immigrant behavior, especially immigrant

\footnotetext{
${ }^{219}$ The "Fake" Installment Business, supra note 174, at 27.

${ }^{220} \mathrm{Id}$.

221 Id. at 31 .

222 Id. at cover page.

${ }^{223} \mathrm{Id}$. at 32.

${ }_{225}^{22} I d$. at 34.
} 
women's consumer habits, while also regulating the selling practices of primarily immigrant vendors and peddlers.

In the interim, before such legislation could be passed, the pamphlet proposed the elimination of body executions - that is, the issuing of arrest warrants-for amounts less than $\$ 75 .^{226}$ Recognizing that vendors would respond by restricting credit to the poor, the pamphlet declared that such restrictions were beneficial. ${ }^{227}$ Responding to potential critics, the pamphlet posited with subtle sarcasm, "Again it is argued that such a limitation of credit will work injury by making it impossible, for example, for a woman to buy a sewing-machine on installment ... This is, after all, but another appearance of the traditional widow and orphan who did such a valiant service in blocking early factory and labor legislation.,228 University Settlement, Rosalie Loew, and the Legal Aid Society eventually launched, and won, a campaign for legislation that prohibited body executions for amounts less than $\$ 100 .^{229}$ Having failed to prohibit the purchase of luxury items by the poor on installment, the settlements had to satisfy themselves with the reform of legal procedure rather than the control of poor consumers' behavior.

Beyond the substance of the report and pamphlet, we can recognize how the settlement conceived of law and the methodology it used. Law did not consist of abstract legal concepts articulated by appellate courts. Law was on the ground, at once producing and a product of the larger social and political economy. It was what happened everyday on the streets, in homes, stores, police precincts, and courts. In the ideal, legal reform for the settlements would involve legislatures, judges, the lower courts' administration of daily justice, and how people actually behaved. Again sociological jurisprudence would later echo such methodologies.

The preceding discussion also shows how settlement houses imported their own prejudices and preconceptions into defining both problems and solutions. In the case of installment contracts, the settlement consistently saw that the entire process, including the law, was abusive. Ultimately, however, it was problematic people-the immigrant consumer and vendor-whom it sought to regulate and condemn. Yet, in some ways, these immigrants whom the settlements sought to Americanize were engaging in the most American of practices-buying and selling consumer goods on credit.

\section{THE SETTLEMENT HOUSES AND THE MUNICIPAL COURTS}

The previous Parts addressed how settlement houses interacted with law in settings other than courts. This article has argued that settlements understood law as part of the quotidian and tended to locate law in the streets, home, and neighborhood. Here, the Article turns to how the

${ }^{226} I d$. at 36 .

${ }^{227}$ Id. at 37.

${ }^{228} \mathrm{Id}$.

${ }^{229}$ Id. at 45; MAGUIRE, supra note 2 at 111-12. 
settlements worked with and in New York's lower courts. One hallmark of New York's three major settlement houses-University, Greenwich, and Henry Street-was direct involvement in the lower courts of New York City. That said, the settlements did not privilege the courts as the primary place where law was created and shaped. Rather, courts were simply among many locations where law was manifested. ${ }^{230}$ One principal characteristic of the settlement houses' legal work was a fixation on trial courts and a lack of interest in appellate courts or the appellate process. This emphasis, in turn, highlights their understanding that the lower trial courts were community institutions where neighbors, lawyers, judges, court personnel, and law interacted. It further highlights their concern with the everydayness of law, and their rejection of abstract judicial and legal doctrine, arguing that law occurred on the ground. This interest and involvement in courts went even further as settlement workers, men and women, served as court officials. Further, through investigation, study, and working in and with the courts, women settlement workers became part of the daily life of the city's lower courts. Similar to the way in which women settlement workers forged an avenue through which they could work with, and at times through municipal government, so too did they craft a role for themselves within the municipal courts. As we shall see, this result was most easily accomplished when issues involved women, children, and the home.

This Part examines two ways that the settlements worked concretely in the courts. First, it analyzes how settlement workers created a role for themselves in eviction proceedings. Here they acted as investigators, arbitrators, and judicial advisors. Second, settlement workers were among New York's first probation officers. In both capacities, settlement workers exercised significant power and discretion through the court system and, once again, the behavior of immigrants received intense scrutiny. Further, in these two areas, settlement workers repeatedly asserted that justice had to be individualized based on particular facts and circumstances.

\section{A. The Courts, Eviction, AND SETtLement Workers}

The first sustained effort between New York's municipal courts and the settlement houses began in 1897, when the head resident of University Settlement attended eviction proceedings in one of the municipal courts on the Lower East Side. ${ }^{231}$ An increase in the number of evicted families seeking aid at the settlement prompted his visit. ${ }^{232}$ During discussions with a number of the judges who presided over these cases, one declared, " $[\mathrm{H}] \mathrm{e}$ had often felt the need of Court [sic] visitors who could investigate Eviction [sic] cases more thoroughly than it was possible ... to do in the

\footnotetext{
${ }^{230}$ Christopher Tomlins makes the argument that even legal progressives and reformers in the early twentieth century privileged courts as a site where law was made. Tomlins, supra note 82, at 936-38. As this Article demonstrates, the settlement houses did not privilege the courts.

${ }^{231}$ Report of the Council of University Settlement, Records of University Settlement Society of New York, in THE JaCOBS S. EISENGER COLleCTION, WISCONSIN HisTORICAL SOCIETY, at Box 3 (Jan. 1897). ${ }^{232} I d$.
} 
very brief examination ... [he] made." ${ }^{233}$ With the support of the judges, University met with workers from Henry Street and College Settlement. ${ }^{234}$ Together, they formed a committee to study who was being evicted, why they were being evicted, and how the settlement might work with the courts. ${ }^{235}$ Various settlements workers immediately began to visit families facing imminent eviction. ${ }^{236}$ College Settlement wrote that the committee "looked up every family" in the neighborhood who had received eviction notices. ${ }^{237}$

This work required the committee and the court to cooperate closely. The clerk of the court provided the committee with the names, addresses, and other information for each eviction case. ${ }^{238}$ Then a committee member would visit the family and landlord to learn the reasons for eviction. ${ }^{239}$ In the first months of operation, settlement workers visited 1,132 families, an extraordinary number. ${ }^{240}$ After each visit, a worker prepared a written memorandum containing the facts surrounding the eviction, and provided it to the court. ${ }^{241}$ Of particular concern to the committee was "prevent[ing] the eviction of worthy tenants."242 Who was "worthy", of course, was determined by the settlement worker, thus investing each worker with a great deal of discretion. ${ }^{243}$ The committee's work was deeply fact intensive and concerned with justice in each case, not the application of abstract legal rules. For the settlement houses, justice had to be individualized, based on particularized facts and not remote legal principles. The downside of justice in the individual case was that settlement workers now overtly brought into judicial determinations highly subjective concepts such as who constituted "worthy" tenants. Although we cannot know for sure, cases of tenants who were worthy probably were those where a husband was employed, where the home was neat, and where settlement workers did not detect what they viewed as immorality. ${ }^{244}$

The committee found that landlords generally were not unfair in evicting tenants but quite lenient. ${ }^{245}$ Of the 1,132 cases investigated, committee workers determined that 313 families needed assistance; others had vacated, paid rent, or were at fault. ${ }^{246}$ With these 313 cases, the committee, working with the court, tenants, and landlords, assisted in paying back rent, negotiated additional payment time, and received various

${ }^{233} \mathrm{Id}$.

${ }^{234} I d$.

${ }_{235}^{235}$ See College Settlement Seventh Annual Report 20 (1896).

${ }^{236}$ Report of the Council of University Settlement, supra note 231.

${ }^{237}$ See College Settlement Seventh Annual Report, supra note 235.

${ }^{238} \mathrm{Id}$.

${ }^{239} \mathrm{Id}$.

${ }^{240} \mathrm{Id}$.

${ }^{241}$ Report of Council of University Settlement, Records of University Settlement Society of New York, in THE JACOB S. EISENGER COLLECTION, WISCONSIN HISTORICAL SOCIETY, Box 3 (Apr. 1897).

${ }^{242}$ Report of Council of University Settlement, Records of University Settlement Society of New York, in THE JACOB S. EISENGER COLLECTION, WISCONSIN HISTORICAL SOCIETY, Box 3 (Feb. 1897).

${ }^{243}$ Report of Council of University Settlement, supra note 241.

244 See generally GORDON, supra note 52 (discussing what constituted "worthy" in the context of mothers' pensions).

${ }^{245}$ Report of Council of University Settlement, supra note 231.

${ }^{246}$ Report of Council of University Settlement, supra note 241. 
concessions from landlords. ${ }^{247}$ As one report stated, "A very decided majority of the cases investigated have been settled by arbitration or by the presentation of the facts learned to the Judge to guide him in his decision." 248 Thus, the committee took an extraordinarily active role functioning as arbitrators between landlords and tenants. If they were unable to resolve the dispute, a committee member would act as a judicial advisor. ${ }^{249}$ One committee member boasted, "The judge has repeatedly told us that we help him much, and has decided in almost every case as we have recommended; and as far as I know only one worthy family has been evicted. $" 250$

Here, we see private individuals essentially functioning as court personnel and swaying judicial determinations. We can only wonder what landlords and tenants must have thought as committee members knocked on their doors and peppered them with questions. Surely, they must have understood the workers as court personnel to whom they were compelled to speak. Further, it appears that the committee was able to circumvent all rules of evidence, providing the court with information and background that it otherwise would not have been able to admit. ${ }^{251}$ The committee saw such information as crucial to the determination of each individual case. ${ }^{252}$

Although committee documents do not discuss the individuals who conducted the eviction investigations or arbitrations, we can assume that men and women participated, as the committee was composed of workers from University Settlement (men and women), College Settlement (all women), and Henry Street (all women). Thus, middle-class and elite women conducted investigations, worked in the courts, and asserted considerable influence among judges.

\section{B. SETTLEMENT WORKERS AS PROBATION OFFICERS}

As settlement houses investigated how law functioned in the courts and actively began to work with the courts, settlement workers became actual court employees, functioning primarily as probation officers. Although scholars have devoted considerable attention to the development of probation work in the Chicago juvenile courts and the role that various women's organizations and settlement houses played in supporting these courts, probation in New York City's courts has received little attention. New York followed a model different from that in Chicago. In New York, probation developed in the adult criminal courts, rather than in the more feminized and experimental space of juvenile courts, as it did in Chicago. ${ }^{253}$

\footnotetext{
${ }^{247} I d$.

${ }^{248}$ Report of Council of.University Settlement, supra note 242.

${ }_{259}^{249}$ Id.

250 Id.

${ }^{251} I d$.

${ }^{252}$ Report of Council of University Settlement, supra note 241.

${ }^{253}$ On the history of juvenile courts, see ELIZABETH J. CLAPP, MOTHERS OF ALL CHILDREN: WOMEN Reformers aNd the RISE OF JUVENILE COURTS IN PROGRessive ERA AMERICA (1998); DAVID S. TANENHAUS, JUVENILE JUSTICE IN THE MAKING (2004); WILLRICH, supra note 55.
} 
In 1901, the New York legislature passed an act allowing offenders over sixteen to be sentenced, at the court's discretion, to probation in lieu of jail. ${ }^{254}$ The legislature did not authorize salaries for probation officers, intending instead that police officers fill these positions. ${ }^{255}$ Soon after enactment of the legislation, a number of New York City judges began discussions with settlement house leaders, exploring the possibility of settlement workers serving as probation officers. ${ }^{256}$ Settlement workers believed that this arrangement was crucial, as they deemed police officers unfit for these positions. ${ }^{257}$ They asserted that policemen were hostile to defendants, that their work was "perfunctory" and conducted in a "military way," and that they did not "seriously study a case.",258

In contrast, highlighting both a class bias and their understanding of expertise, settlement workers opined that the ideal probation officer would be college educated, and would steep him or herself in the facts and circumstances of the defendant's life. ${ }^{259}$ One settlement article argued that a probation officer must possess "an acute knowledge of human nature, experience in the ways of criminals, the ability to distinguish truth from falsehood, and especially, a personality that compels the respect of the judge."

Reminiscent of their approach to eviction cases, the settlements believed that the probation officer's role was to contextualize a case, grounding it in facts and particulars. As one settlement article explained, "Much pertinent information is excluded from open court by the formal rules of evidence ... [Probation] proves a great service when some trustworthy person interviews the prisoner, investigates the circumstances of the crime, and makes a confidential report to the judge. ${ }^{261}$ In the process of putting a case in context and presenting it to a judge, the probation officer possessed an inordinate degree of discretion, functioning outside formal legal rules. Indeed in the settlement workers' view, formal evidentiary rules prevented the court from learning a defendant's individual life history and formulating the correct sentence.

Fred King of University Settlement and Florence Cross of College Settlement were selected to serve as probation 'officers. ${ }^{262}$ Florence Cross, who was in her twenties and a college graduate, was assigned to Judge Deuel's courtroom in the Essex Market Court, and was placed in charge of

\footnotetext{
${ }^{254}$ UNIVERSITY SETTLEMENT, Organization of Probation Work in New York Courts, in UNIVERSITY SETTLEMENT STUDIES AND ANNUAL REPORT 27-28 (1904).

${ }_{255}^{25}$ Id. at 28

${ }^{256} I d$.

${ }^{257}$ Maurice F. Parmelee, Probation Work in the Courts of Special and General Sessions, in UNIVERSITY SETTLEMENT STUDIES AND ANNUAL REPORT 22, 25-26 (Apr. 1904); see also LAWRENCE M. FRIEDMAN, CRIME AND PUNISHMENT IN AMERICAN HISTORY 162-63 (1993) (describing the development of the early probation system by John Augustus during the mid-nineteenth century as well as the subsequent passage of state probation laws).

${ }_{258}^{259}$ Parmelee, supra note 257.

259 Id.

${ }^{260}$ UNIVERSITY SETTLEMENT, supra note 254.

${ }^{261} I d$.

${ }^{262}$ Diary Entry of Florence Cross Kitchelt (Nov. 8, 1901), in FloReNCE CROSS KITCHELT PAPERS,
} (Sophia Smith Collection of Smith College). 
women sentenced to probation. ${ }^{263}$ As a woman, it was assumed by the settlement house and court that she had insight into the problems of poor and working class women-problems that male settlement workers did not possess. ${ }^{264}$ Conversely, she was presumed to lack such insight into male defendants. ${ }^{265}$ This is evidence of what historian Robin Muncy calls the "dominion" that women settlement house workers had over issues involving women and children, and the expertise and role that they constructed for themselves. ${ }^{266}$

On Cross's first day in court, the judge informed her that he would not assign her any cases, as he did not believe in probation. ${ }^{267}$ However, he appointed her an officer of the court, and administered an oath whereby she promised to uphold the Constitutions of the United States and New York State, and fulfill her yet to be determined duties as a probation officer. ${ }^{268}$ Though disappointed and perplexed by the judge's position, Cross took pride in being given the oath, carefully recording this moment in her diary. ${ }^{269}$ Cross, a young woman with very little practical training, was now a court official. Appearing for work on a semi-daily basis, she was told repeatedly by Deuel that he had no cases to assign her. ${ }^{270}$ By contrast, Fred King, who was paid a salary by a private donor to engage in full-time probation work, readily received cases. ${ }^{271}$ Although King was assigned to a different judge, this contrast perhaps points to Deuel's distrust, not only of probation, but of a female probation officer. Furthermore, like Annete Fisk's unpaid legal work at University Settlement, Cross was allowed to engage in such work so long as she did not receive remuneration. ${ }^{272}$

When Deuel's rotation through the Essex Court ended, Judge May took the bench. ${ }^{273}$ Cross wrote that May, "most affable[,] said he would do everything in his power to assist me and asked me to make myself at home ... Whether he will give me any cases remains to be seen." ${ }^{274}$ Soon Cross was "sitting directly beside" May on the bench where he frequently turned to her "for advice."275 Cross wrote: "I had to base my opinions on the people and so would reply, 'Why, this wife is painted a bit, gaudily dressed. She's gay. The husband's face is furrowed with care and grief. He must be in the right." 276 Cross's expertise, like that of other settlement workers, was

${ }^{263}$ Diary Entry of Florence Cross Kitchelt (Oct. 22, 1901), in FLORENCE Cross KITCHELT PAPERS, (Sophia Smith Collection of Smith College).

${ }^{264}$ See ESTELLE FREEDMAN, THEIR SISTERS' KeEPERS: WOMEN'S PRISON REFORM IN AMERICA, 18301930 , at $131-34(1981)$.

${ }^{265} \mathrm{Id}$.

${ }_{266}^{266}$ MUNCY, supra note 51, at 4.

${ }^{267}$ Diary Entry of Florence Cross Kitchelt, supra note 263.

${ }^{268} I d$.

${ }^{269} I d$.

${ }^{270} I d$.

${ }^{271} I d$.

${ }^{272}$ Diary Entry of Florence Cross Kitchelt, supra note 262.

${ }^{273} \mathrm{Id}$.

${ }^{274}$ Diary Entry of Florence Cross Kitchelt (Nov. 9, 1901), in FloRENCE CROSS KITCHELT PAPERS, (Sophia Smith Collection of Smith College).

${ }^{275}$ Diary Entry of Florence Cross Kitchelt (Nov. 12, 1901), in FloRENCE Cross Kitchelt PAPERS, (Sophia Smith Collection of Smith College).

${ }^{72} \mathrm{Id}$. 
based upon a supposed knowledge of the characteristics and habits of the poor and working class of New York. These perceptions manifested themselves in a "womanly" ability to read people's dress, expressions, relations between a husband and wife, and how they conformed, or failed to conform, to gender norms. The irony is that Cross, an unmarried woman, relatively new to the city, was assumed to have this ability by virtue of her class, race, gender, and institutional affiliation.

Even with May's support, Cross wrote of her discomfort in court, feeling she "wasn't wanted," and finding policemen and court personnel "coarse." ${ }^{277}$ At times, one of the younger court clerks brushed against her as he passed. ${ }^{278}$ Cross's feelings highlight the difficulty of women entering the male space of the courtroom. In a case involving a wife's claim of abandonment, the husband's attorney suggested the matter be discussed without Cross present, as it involved "delicate" issues. ${ }^{279}$ Cross, with the judge's support, remained, reasoning that if the wife was forced to hear such things, she too could "endure it." ${ }^{280}$ It was worse, Cross felt, that the woman should have to tell "her private troubles to men alone." ${ }^{281}$ Yet, as will be seen, Cross's sympathy did not necessarily reside with poor and working class women.

Approximately one month after Cross received her appointment, May assigned her a case. ${ }^{282}$ Dora Feinstein was nineteen and living in a "disorderly house" on the Lower East Side. ${ }^{283}$ Although the judge intended to sentence Dora to one month's probation, Cross convinced him that two months were necessary. ${ }^{284}$ Cross instructed Dora to report to her once a week, and informed her that, "[I] could arrest her as soon as I knew she was not doing right, and then I told her I would help her in any way I could." 285 Cross wielded real power in determining sentences, which she was not hesitant to use, and here, she used her authority and access to state power to threaten Dora in an attempt to control her behavior.

Soon Cross received another case - this one concerning an "old" woman arrested for drunkenness who lived on the top floor of a rear tenement. ${ }^{286}$ Cross visited the house and found it "full of ancient dirt and squalor. Lower floors full of negroes. 2877 She continued,

As I went up those narrow stairs I said to myself, I'm in it! So I was glad to have some woman call come in! My Lady Drunk, Kate McEntee was

${ }^{277}$ Diary Entry of Florence Cross Kitchelt (Nov. 14, 1901), in FLORENCE Cross KitchelT PAPERS, (Sophia Smith Collection of Smith College).

278 Id.

${ }^{279} I d$.

${ }_{281}^{280} \mathrm{Id}$.

${ }^{281}$ Id. For a sense of the general ambiance of the Essex Court, see Mary Robert Smith, The Social Aspect of New York Police Courts, 5 AM. J. Soc. 145 (1899).

${ }^{282}$ Diary Entry of Florence Cross Kitchelt (Nov. 21, 1901), in FlorenCE Cross Kitchelt PAPERS, (Sophia Smith Collection of Smith College).

${ }_{283} I d$.

${ }^{284} \mathrm{Id}$.

${ }_{286}$ Id.

(Siary Entry of Florence Cross Kitchelt (Nov. 30, 1901), in FlORENCE CROSS KitCHELT PAPERS, (Sophia Smith Collection of Smith College).

${ }_{287}$ Id. 
on an old couch ... Three middle aged or elderly women stood about ... We had a gay time. They were all irish [sic] and we joked together. They volunteered much information without my questioning ... They marveled over this parole law-a new thing! . . . They were so pleased that I didn't allow Kate to be railroaded! And they were so puzzled on this probation system. Kate spurned the idea of going into a home and I could feel the other women all wanted to laugh at the idea. ${ }^{288}$

Cross perceived that the women saw her as possessing real power within the court system and being instrumental in Kate's escaping a jail sentence. Simultaneously, the women understood that probation did not provide a deterrent to their behavior and that Cross ultimately offered them little. The women seemed amused with any notion that Cross could, or would, exert real control. Where scholars might understand that Cross and the entire probation system implicated mechanisms of social control, the women did not grant the system such power. Cross, nonetheless, was thrilled to be immersed in what she viewed as a world that was promiscuous, a world in which the races mixed, and where households appeared deeply disordered. This, for Cross, was the authentic experience of urban poverty that she sought.

As Cross received additional cases, she contemplated requesting a police badge, which she believed would provide her with "great protection." 289 Precisely whom she sought protection from is unclear, but it reflected Cross' desire for a physical indicium of the state power she wielded. Cross recognized, however, that the contours of such power were vague. She lamented that she had too many cases of older drunk women where she could do little, and complained of her inability to convince the judges, who rotated through the bench, to give her different cases. ${ }^{290}$

In February 1902, Cross unexpectedly received the case for which she was waiting. ${ }^{291}$ Upon returning home from a probation visit in Brooklyn, Cross found a young Jewish woman, Sadie Rubin, waiting for her at College Settlement. ${ }^{292}$ Sadie had been brought directly from court and put in Cross's charge. ${ }^{293}$ Upon Sadie's mother's complaint, Sadie had been arrested for being incorrigible and she was now awaiting trial. ${ }^{294}$ We can safely assume that Cross immediately began to question Sadie.

\footnotetext{
${ }_{289}^{288} I$.

Id.

${ }^{290}$ Diary Entry of Florence Cross Kitchelt, supra note 286.

291 Diary Entry of Florence Cross Kitchelt (Feb. 7, 1902), in FlorenCE CROSS KITCHELT PAPERS, (Sophia Smith Collection of Smith College).

${ }_{292}^{293}$ Id.

294 The charge of incorrigibility was utilized as a sweeping tool bv courts to place "wrong-leaning. wrong-living youths" in reform-oriented settings. Randy Frances Kandel \& Anne Griffiths, Reconfiguring Personhood: From Ungovernability to Parent Adolescent Autonomy Conflict Actions, 53 SYRACUSE L. REV. 995, 1021 (2003). Girls were the primary targets of incorrigibility charges, which focused on "non-criminal behavior" such as sexual activity, while boys were brought under court supervision more frequently for criminal behavior. Anne Bowen Poulin, Female Delinquents: Defining Their Place in the Justice System, 1996 WIS. L. REV. 541, 544-45. In 1886, the New York legislature passed the so-called "incorrigible girl statute," which served to punish and reform girls ages twelve and above who engaged in behavior such as "frequenting the company of thieves," prostitution, and parental
} 
Cross wrote in her diary that Sadie told her that at fourteen or fifteen, she had been "taken" and put in a "bad house" by a man who beat her and demanded any money she earned. ${ }^{295}$ After a couple of months, her mother found her, and Sadie returned home. ${ }^{296}$ Sadie, now eighteen or nineteen, was unable to read or write, an unemployed domestic servant, and in Cross' words: "Sweet and childlike and seemingly uncontaminated."297 The ostensible purity that Cross observed made Sadie a perfect subject for reform. ${ }^{298}$ As if preparing Sadie for a wedding, the settlement workers provided her with white ribbons, dressed her in their clothing, and allowed her to stay at the settlement house before her trial date. ${ }^{299}$ Here is a concrete example of the rescue fantasy in which middle class women reformers often engaged. Historian Linda Gordon writes that women reformers "indulged in rescue fantasies, imagining themselves raising downtrodden women up to the norms of respectability they deemed essential to proper family and polity.",300

Cross and her fellow settlement workers believed that with the help of the state, and using themselves as role models, they could uplift Sadie and young women like her into a life of at least working-class respectability. For many settlement workers, respectability constituted compliance with middle-class conceptions of the appropriate behavior for working class women which included strict sexual morality, steady work, and often abandoning immigrant customs. ${ }^{301}$ Complicating this analysis is the fact that Sadie was not passive, as she too seems to have longed for uplift-the possibility to transform herself and the conditions of her life. As we shall see, Cross's fantasies and Sadie's longings played off each other.

As Cross wrote in her diary Sadie told her:

I will not go home, I never go home. I want to be put away, one year, two, three, jus' as you say. I will be Catholic, Protestant, Christian, anythingbut I never be a Jew. My mother is-Jew. I wish you my mother, not her. I go away for three years lady-she never know where I am... She say I go with bad boys: Why she let them come to the house then? I will lie down on floor and croak before I go home. She is no good woman: This is now her third husband: she divorce the other two ... I go to work when I am eight year old. I never was to a school. She want me to marry a boy I don't want: he a greenie. ${ }^{302}$

\footnotetext{
defiance (the statute was an amendment to New York's original 1882 "wayward minor laws" which targeted female juvenile prostitutes between the ages of fourteen and twenty-one). In 1923, the statute was expanded to apply to girls ages sixteen to twenty-one who abused drugs or alcohol. The statute did not apply to boys until 1925. Cheryl D. Hicks, "In Danger of Becoming Morally Depraved": Single Black Women, Working-Class Black Families, and New York State's Wayward Minor Laws, 1917-1928, 151 U. PA. L. REV. 2077, 2082-83 (2003).

${ }_{295}$ Diary Entry of Florence Cross Kitchelt, supra note 286.

${ }^{296} I d$.

${ }^{297} \mathrm{Id}$.

${ }_{299}^{298} I d$.

${ }^{299} \mathrm{Id}$.

${ }^{300}$ GORDON, supra note 52, at 44.

${ }^{301} \mathrm{Id}$.

${ }^{302}$ Diary Entry of Florence Cross Kitchelt, supra note 286.
} 
Here, Cross purportedly heard Sadie say that what she longed for was a life of bourgeois morality - to be taken out of her immigrant home, to become a Christian, and to receive an education. Indeed, Sadie seemed to have yearned to lose her mark as "other"; in a certain sense she wanted to become fully Americanized. To confirm Sadie's story and to report to the court, Cross engaged in an investigation of Sadie's home life and described the mother as a "dirty, coarse, harried, creature." ${ }^{\text {"303 }}$ The nameless mother was portrayed by Cross as somewhat less than human, clearly lacking in appropriate mothering and housekeeping skills. ${ }^{304}$

At Sadie's trial, the mother pleaded with the judge to send Sadie home, and she sought to withdraw her charge of incorrigibility. ${ }^{305}$ Cross, however, believed that the mother only wanted Sadie's potential job earnings and, upon Cross's insistence, the judge sentenced Sadie to the Bedford Reformatory for Women for an indeterminate sentence. ${ }^{306}$

We will never know Sadie's full story, but we can analyze the complex role played by the state and the various participants in her case's disposition. Sadie's mother, like many working class parents, called upon the state, bringing a legal action for incorrigibility, when she no longer could control her child. ${ }^{307}$ She sought to invoke state power when her own power failed. Sadie keenly perceived that, in Cross, she found an ally who could use state power for what Sadie understood to be her own benefit. Indeed, the story that Sadie told Cross, or at least what Cross heard, touched on all the issues that many settlement workers held dearest. This perhaps indicates Sadie's own astute awareness of what constituted a sympathetic story. Sadie spoke of white slavery, an education curtailed by the need to work, her mother's attempt to force her to marry a newly arrived immigrant whom she did not love, her mother's alleged immorality, and her Jewishness, which she sought to shed. These topics went to the heart of what could make the immigrant into an American-education, a marriage based upon love, sexual morality, and assimilation. ${ }^{308}$ Sadie

${ }^{303} I d$.

${ }^{304} I d$.

${ }^{305} \mathrm{Id}$.

${ }^{306}$ The creation of New York's reformatories for women was spearheaded by elite women. Josephine Shaw Lowell played a significant role in lobbying Albany to establish these reformatories, first built in New York in the 1880 s. The reform impulse underlying such efforts was that young women, defined as under thirty, would be placed in a wholesome rural environment, separated from men, and guided by proper women. In reformatories they would receive vocational training, primarily in sewing, laundry, and kitchen work. See FREEDMAN, supra note 264 (discussing creation of women's reformatories); ANTHONy M. PlatT, The ChIldSAVERS: ThE INVENTION OF DELINQUENCY 59-61 (2d ed. 1977) (describing the reformatories' "industrial training" programs); JOAN WAUGH, UNSENTIMENTAL REFORMER: THE LIFE OF JOSEPHINE SHAW LOWELL 134-38 (1997) (discussing the establishment of Bedford and the role that elite women played). Regarding the use of indeterminate sentences, see LAWRENCE M. FRIEDMAN, CRIME AND PUNISHMENT IN AMERICAN HISTORY, 159-63 (1993); Albert W. Alschuler, The Changing Purposes of Criminal Punishment: A Retrospective on the Past Century and Some Thoughts About the Next, 70 U. CHI. L. REV. 1, 2 (2003).

307 See MARY ODEM, DELINQUENT DAUGHTERS: PROTECTING AND Policing Adolescent Female SEXUALITY IN THE UNITED STATES, 1885-1920 (1995) (Regarding this issue and the construction of female juvenile delinquency during the Progressive era).

308 See generally NANCY COTT, PUBlic VOWS: A History OF MARRIAGE AND THE NATION (2000) (regarding making immigrants into Americans through proper marriages and sexual conduct); PAMELA HAAG, CONSENT: SEXUAL RIGHTS AND THE TRANSFORMATION OF AMERICAN LIBERALISM (1999). 
supposedly implored Cross to use her influence and authority to have the court send her to a state institution where she would be away from her mother and receive an education and skills. We do not know what Cross told Sadie about Bedford, but it appears that Sadie believed that a better life awaited her. Bedford would transform Sadie into an American, perhaps the type of woman Sadie met at College Settlement.

We must also be cognizant of Cross's perceptions. She believed that Sadie's mother was a bad influence, immoral, and lacking in maternal love and care. Cross understood that Sadie wanted to find a new home. Further, Cross had previously visited Bedford on a settlement outing and was acquainted with former College Settlement worker Katherine Davis, the superintendent of Bedford. ${ }^{309}$ College Settlement also appears to have had a close relationship with Bedford, even sending settlement workers there to run various programs. ${ }^{310}$ Cross did not perceive Bedford as a prison, or even as a reformatory, but rather as a training school where Sadie would receive an education. As Cross wrote, "I do not fear the effect of the stigma 'reformatory' at all, and at Bedford Miss Davis will put her with the best girls, and moreover she will get systematic training - school half-a day.",311 Cross thus imagined Bedford as a boarding school for working-class girls set far away from the city. Perhaps she even fantasized that Bedford was an extension of the settlement house. ${ }^{312}$

During Sadie's imprisonment, she began a remarkable correspondence with Cross. ${ }^{313}$ Although Sadie's letters were dictated to reformatory workers and usually began with how she enjoyed her surroundings and received good treatment, they also expressed a strong desire to see her mother. ${ }^{314}$ Even more revealing, the letters document the profound influence that Cross had over Sadie, Sadie's extraordinary affection for Cross, and her longing to find a better life that she believed Cross and the settlement could provide. ${ }^{315}$ Sadie wrote, "[N] $]$ ow I know you are coming up to see me soon because I want to see you very bad when I go to bed I think of you always. I carry your picture I love to look at it and I kiss it every night ... I kiss your sweet face it is the only comfort I have in this

${ }^{309}$ Diary Entry of Florence Cross Kitchelt (Jan. 26, 1902), in FlorenCE Cross Kitchelt PAPERS, (Sophia Smith Collection of Smith College).

${ }_{310}$ See FREEDMAN, supra note 264, at 133.

${ }^{311}$ Diary Entry of Florence Cross Kitchelt, supra note 286. Katherine Davis had worked in the College Settlement house in Philadelphia. She later returned to school to receive a Ph.D. in political economy from the University of Chicago. After serving as superintendent at Bedford, the mayor of New York City appointed her Commissioner of Correction in 1914. On Davis, see ElLEN FITZPATRICK, ENDLESS CRUSADE: WOMEN SOCIAL SCIENTISTS AND PROGRESSIVE REFORM (1990).

${ }_{312}$ In some ways, Bedford was an extension of College Settlement, as both were part of the female world of reform. Furthermore, the settlement and Bedford shared an understanding of the role of law in making immigrants into Americans. Historian Estelle Freedman writes that Katherine Davis, the superintendent of Bedford, "explained that she wanted inmates to learn that the law was not merely an abstract authority, but a method of conducting relationships between people. Therefore, she started a series of talks on law beginning with its origins and development, working up to American democracy." FREEDMAN, supra note 264, at 132. Davis may have developed such an understanding of the importance of law and its dissemination while working at College Settlement.

${ }^{313}$ Letters from Sadie Ruben to Florence Cross (Feb. 14, 1902-Oct. 12, 1903), in FLORENCE CROSS KITCHELT PAPERS, (Sophia Smith Collection of Smith College).

${ }_{315}^{314} \mathrm{Id}$.

${ }^{315} \mathrm{Id}$. 
world."316 Subsequent letters, with an increasing sense of urgency, beseeched Cross to visit, described her mother's visits, and voiced her increasing desire to return home. ${ }^{3 / 7}$

Cross was adamant that Sadie remain in the reformatory and terminate her family ties. In one letter Sadie wrote, "I want you to explain what you meant about my home not being good enough if you want me to forget my mother I will certainly do it for your sake as I will do anything to please you." ${ }^{, 318}$ As months went by, Sadie's desire to be released grew, and she continually pleaded with Cross to allow her to live in the settlement. ${ }^{319}$ Cross seemed to ignore the letters and Sadie began desperately to seek to be reunited with her mother. ${ }^{320}$ Eventually, after nineteen months of confinement, Sadie's mother hired an attorney who convinced the court to release Sadie. ${ }^{321}$ Meanwhile, Cross had left the settlement due to ill health. ${ }^{322}$ In what appears to be her last letter to Cross, Sadie wrote upon her return home, "How happy I was to be in my own home, sweet home.",323

\section{CONCLUSION}

A study of the ways that settlement houses interacted with law provides us with important insight into fin-de-siecle urban legal culture. Indeed, settlement houses' multiple legal activities included providing direct legal services, popularizing and spreading legal knowledge, enforcing laws, lobbying for reforms, and working in the courts. Taking this expansive view, settlements saw law as part of the fabric of the everyday, defining and affecting the structure of the home, neighborhood, and city. In doing so, they gave life to the practice and methodology of sociological jurisprudence.

As we have seen, the on-the-ground legal work in which settlements participated often was conducted by middle class and elite women settlement workers. Through such institutional affiliations, their claim to knowledge based upon first-hand experience of the life of a community, and the ways in which they defined and articulated problems, these women accrued unprecedented access to state power-a state power that was inherently local, springing from the neighborhood, and spreading through the municipality. In a telling comment, Roscoe Pound, in 1913, referred to the growing regulatory state as "governmental maternalism." ${ }^{144}$ This label

\footnotetext{
${ }^{316} \mathrm{Id}$.

${ }^{317}$ Letters from Sadie Ruben to Florence Cross (June 2, 1902, Sept. 11, 1902, Oct. 14, 1903), in FLORENCE CROSS KITCHELT PAPERS, (Sophia Smith Collection of Smith College).

${ }^{318}$ Letter from Sadie Rubin to Florence Cross (June 2, 1902), in FlORENCE CROSS KITCHELT PAPERS, (Sophia Smith Collection of Smith College).

319 Letters from Sadie Ruben to Florence Cross, supra note 313.

320 Letters from Sadie Ruben to Florence Cross (Oct. 12, 1902, Dec. 15, 1902, Feb. 2, 1903), in FLORENCE CROSS KITCHELT PAPERS, (Sophia Smith Collection of Smith College).

${ }^{321}$ Letters from Sadie Ruben to Florence Cross (Oct. 12, 1902), in FlORENCE CROSS KITCHELT PAPERS, (Sophia Smith Collection of Smith College).

322 Id.

${ }^{323}$ Letter from Sadie Rubin to Florence Cross, supra note 320.

${ }^{324}$ Roscoe Pound, The Administration of Justice in the Modern City, 26 HARV. L. REV. 302, 312 (1913).
} 
echoes the sentiments of Lillian Wald and Mary Kingsbury Simkhovitch as they imagined and sought to create an activist state that protected and cared for its citizens, and in which elite and middle-class women would play a significant role. ${ }^{325}$ Justice in this state would be highly individualized, based on investigations of fact and an understanding of social conditions, not on abstract legal principles.

In the late 1890s and early years of the new century, settlements claimed a portion of this power as they sought to Americanize immigrants, police the urban environment, and introduce new models of adjudication into trial courts. While claiming quasi-state power, settlements brought into their work assumptions about class, race, gender, and urban order that often subjected immigrant and working class people, especially women, to the control of the state, while also providing neighbors with newfound claims upon the state.

${ }^{325}$ See supra Part II. 